\title{
Non-productive binding of cellobiohydrolase $i$ investigated by surface plasmon resonance spectroscopy
}

\author{
Florian Csarman - Claudia Gusenbauer • Lena Wohlschlager • Gijs van Erven • \\ Mirjam A. Kabel · Johannes Konnerth $\cdot$ Antje Potthast $\cdot$ Roland Ludwig $(\mathbb{C}$
}

Received: 10 March 2021 / Accepted: 10 June 2021/Published online: 25 August 2021

(C) The Author(s) 2021

\begin{abstract}
Future biorefineries are facing the challenge to separate and depolymerize biopolymers into their building blocks for the production of biofuels and basic molecules as chemical stock. Fungi have evolved lignocellulolytic enzymes to perform this task specifically and efficiently, but a detailed understanding of their heterogeneous reactions is a prerequisite for the optimization of large-scale enzymatic biomass degradation. Here, we investigate the binding of cellulolytic enzymes onto biopolymers by surface
\end{abstract}

Supplementary Information The online version contains supplementary material available at https://doi.org/10.1007/ s10570-021-04002-6.

F. Csarman · L. Wohlschlager · R. Ludwig $(\bowtie)$

Department of Food Science and Technology,

Biocatalysis and Biosensing Laboratory, BOKU

University of Natural Resources and Life Sciences,

Muthgasse 18, 1190 Vienna, Austria

e-mail: roland.ludwig@boku.ac.at

F. Csarman

e-mail: florian.csarman@boku.at

L. Wohlschlager

e-mail: lena.wohlschlager@boku.ac.at

C. Gusenbauer $\cdot$ J. Konnerth

Department of Materials Sciences and Process

Engineering, Institute of Wood Technology and

Renewable Materials, BOKU - University of Natural

Resources and Life Sciences, Konrad-Lorenz-Straße 24,

3430 Tulln, Austria

e-mail: claudia.gusenbauer@boku.ac.at plasmon resonance (SPR) spectroscopy for the fast and precise characterization of enzyme adsorption processes. Using different sensor architectures, SPR probes modified with regenerated cellulose as well as with lignin films were prepared by spin-coating techniques. The modified SPR probes were analyzed by atomic force microscopy and static contact angle measurements to determine physical and surface molecular properties. SPR spectroscopy was used to study the activity and affinity of Trichoderma reesei cellobiohydrolase I (CBHI) glycoforms on the modified SPR probes. N-glycan removal led to no significant change in activity or cellulose binding, while a slightly higher tendency for non-productive binding to

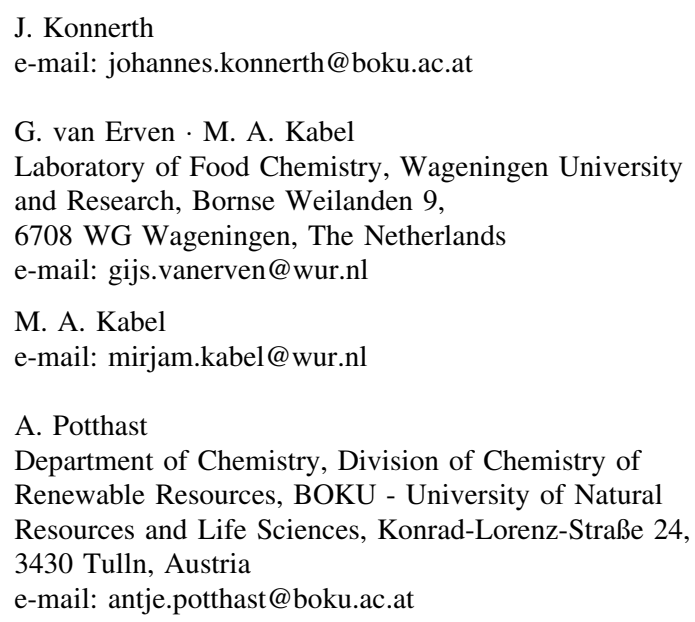


SPR probes modified with different lignin fractions was observed. The results suggest that the main role of the $\mathrm{N}$-glycosylation in CBHI is not to prevent nonproductive binding to lignin, but probably to increase its stability against proteolytic degradation. The work also demonstrates the suitability of SPR-based techniques for the characterization of the binding of lignocellulolytic enzymes to biomass-derived polymers.

\section{Graphic abstract}
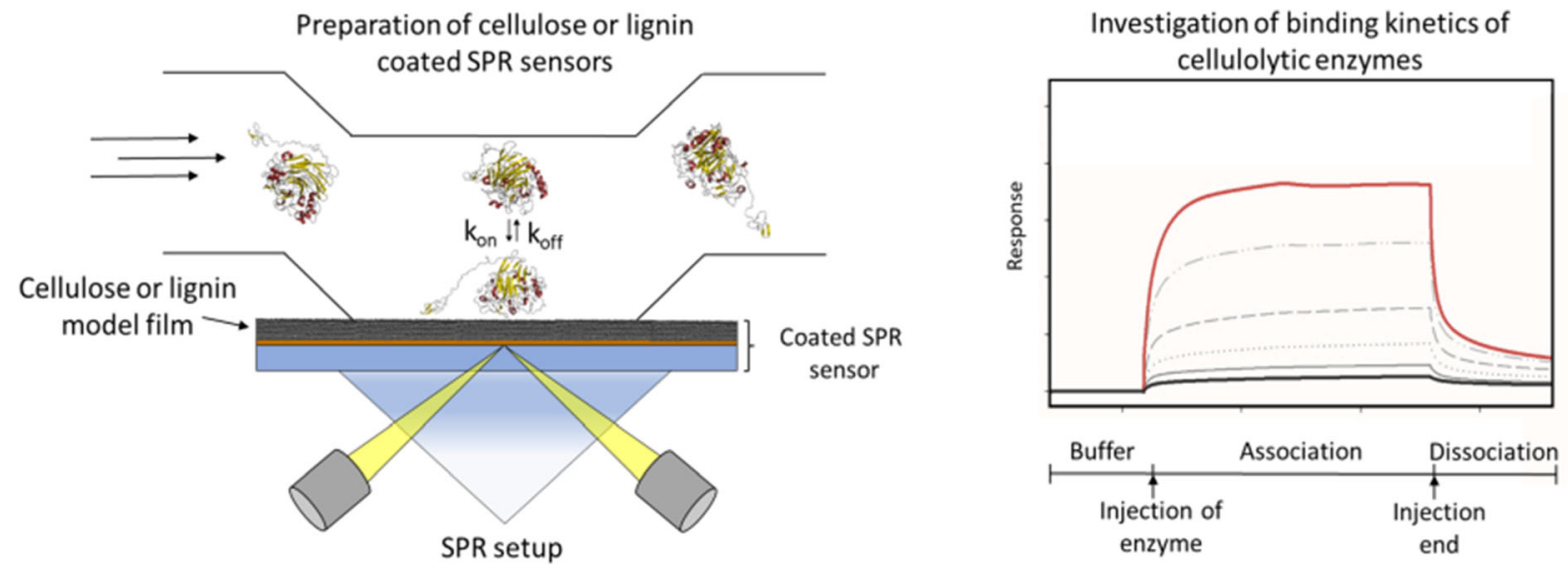

plant cell wall against physical and chemical treatments (Ragauskas et al. 2014; Rinaldi et al. 2016). In comparison to acid- or alkali-based processes, enzymatic hydrolysis of lignocellulose is performed under mild reaction conditions ( $\mathrm{pH}$ and temperature) that saves energy, avoids degradation of reaction products, and reduces the formation of undesirable side-products acting as inhibitors in subsequent fermentation processes (Dos Santos et al. 2016). Enzymatic hydrolysis at industrial scale is facing a variety of challenges
Keywords Cellobiohydrolase $\cdot$ Non-productive binding $\cdot$ Surface plasmon resonance $\cdot$ Biomass hydrolysis · Lignin · Glycosylation

\section{Introduction}

The global climate crisis together with an increasing demand for energy and goods is the driving force of intensified research on sustainable resources. The efficient utilization of lignocellulosic biomass is considered to be a key technology for the transition from fossil resources towards a sustainable economy (Ragauskas et al. 2006; Chandel et al. 2018; De Bhowmick et al. 2018). The concept of modern biorefineries requests that the biopolymers found in lignocellulose are depolymerized and fractionated into fermentable sugars and chemical base stock. The bottleneck of the process is the recalcitrance of the 
Teleman 2009; Heinze 2015). In contrast to the completely amorphous hemicelluloses, cellulose chains are able to interact to regular semi-crystalline fibres and fibrils stabilized by hydrogen bond networks and van der Waals forces.

Lignin is an irregular polymer formed by the free radical polymerisation of the aromatic monolignol precursors coniferyl, sinapyl and p-coumaryl alcohols giving rise to a network composed of $\mathrm{C}-\mathrm{C}$ or $\mathrm{C}-\mathrm{O}-$ linked guaiacyl- $(\mathrm{G})$, syringyl- $(\mathrm{S})$, or $p$-hydroxyphenyl $(\mathrm{H})$ subunits, respectively. The ratio of these subunits differs between individual plant species. While lignin found in herbaceous biomass consists of $\mathrm{G}, \mathrm{S}$ and $\mathrm{H}$ subunits and includes hydroxycinnamic acids, hardwood lignin consists of only $\mathrm{G}$ and $\mathrm{S}$ units while softwood lignin is almost exclusively composed of $\mathrm{G}$ units with small amounts of H subunits (Schutyser et al. 2018; Lourenço and Pereira 2018). Many studies have been devoted to understanding the relation between these fundamentally different lignin structures and overall cell wall recalcitrance towards chemical and enzymatic degradation. However, the underlying mechanisms are still a matter of debate (Huntley et al. 2003; Yoo et al. 2018; Zoghlami and Paës 2019).

Lignin forms a major barrier that limits accessibility of cellulose and hemicellulose by hydrolytic enzymes and additionally, lignin can bind cellulases in an unspecific manner reducing the amount of available active enzymes. (Jeoh et al. 2007; Álvarez et al. 2016; Siqueira et al. 2017) This non-productive binding reduces the efficiency of enzymatic processes. A variety of pretreatment procedures intend to reduce non-productive binding of enzymes by selective lignin removal (Ding et al. 2012) or by thermochemical modification of lignin (Sipponen et al. 2017) to decrease enzyme association with lignin. The development of cellulase preparations less affected by lignin and reduced non-productive binding is suggested as an alternative approach to improve hydrolytic enzyme cocktails (Berlin et al. 2005, 2006).

For lignocellulose saccharification a variety of processive cellobiohydrolases (CBHs), endo- $\beta$-4-glucanases (EGs), and $\beta$-glucosidases supported by hemicellulose-active hydrolases and esterases as well as auxiliary oxidoreductases like lytic polysaccharide monooxygenase (LPMOs) are used to synergistically convert carbohydrate polymers to monosaccharides (Rosgaard et al. 2007; Vaaje-Kolstad et al. 2010; Horn et al. 2012). Although there is some evidence by MD simulations and experimental work that non-productive binding of enzymes to lignin is governed primarily by hydrophobic interactions (Palonen et al. 2004; Chen et al. 2011; Pareek et al. 2013; Rahikainen et al. 2013; Sammond et al. 2014) some other studies also indicate the importance of hydrogen bonding (Pan 2008) and electrostatic interactions (Nakagame et al. 2011) between lignin and biomass degrading enzymes. A common posttranslational modification to increase solubility and decrease the hydrophobic surface properties of extracellular proteins is $\mathrm{N}$ - and $\mathrm{O}$-glycosylation. This protein modification found across eukaryotic species is also involved in efficient secretion, thermal stability, catalytic activity, stability against proteolytic degradation and increase the solubility and hydrophilicity. However, the implications of glycosylation on the binding behaviour of lignocellulolytic enzymes and especially on the interaction with lignin are still not completely clear and experimental challenges interfere with the studies.

Surface plasmon resonance (SPR) spectroscopy represents a surface-sensitive method allowing for the label-free quantification and characterisation of bimolecular interactions in real-time. Today SPRbased methods are commonly applied in different fields including drug development and screening for pharmaceutically active compounds (Patching 2014; Olaru et al. 2015), antibody engineering (Alfthan 1998; DiCara et al. 2018), or clinical analytics and food safety (Piliarik et al. 2009; Situ et al. 2010; Li et al. 2012; Mariani and Minunni 2014). SPR biosensors modified with cellulose thin films have been used to study adsorption behaviour dependent on $\mathrm{pH}$, temperature and ionic strength. Furthermore, the importance of the carbohydrate binding module (CBM) of endoglucanase GH45 from Humicola insolens for substrate binding and efficient catalytic turnover was demonstrated by using cellulose model films on SPR probes (Eriksson et al. 2005a, 2005b). Lignin-modified SPR probes have been successfully employed for the study of the binding and precipitation behaviour of glycinin and $\beta$-conglycinin from soy beans (Salas et al. 2013). An SPR probe modified with milled wood lignin immobilized onto a self-assembled monolayer of methoxypolyethylene glycol thiol (mPEG-SH) was used to investigate the binding of 12-mer peptides to lignin (Yamaguchi et al. 2016; Isozaki et al. 2018). 
In this study, we characterize the binding behaviour of cellulolytic enzymes, especially CBHI, to lignin and cellulose films on SPR probes used as model systems. This experimental setup was applied to investigate the role of $\mathrm{N}$-glycosylation of CBHI from Trichoderma reesei, an important posttranslational modification of extracellular enzymes, for specific binding to cellulose and its proposed function to reduce non-productive binding of enzymes to the types of lignin used.

\section{Materials and methods}

Materials and chemicals

Unless stated otherwise all chemicals and reagents were purchased from Sigma-Aldrich (St. Louis, MO, USA) or Carl Roth (Karlsruhe, GER) and were of highest purity available. High quality water (HQwater, $>18 \mathrm{M} \Omega \mathrm{cm}^{-1}$ ) for the preparation of solutions and buffers was prepared using a SG System (Barsbüttel, GER). Microcrystalline cellulose (MCC) for column chromatography was purchased from Merck (Darmstadt, GER) and particles were fractionated by size using a stack of analytical sieves (Haver\&Boecker, Oelde, GER). Phosphoric acid swollen cellulose (PASC) was prepared from MCC with a particle size of $45-125 \mu \mathrm{m}$ and following a published procedure with modifications (Wood 1988; Kracher et al. 2018). In brief, $4 \mathrm{~g}$ of MCC were treated with $100 \mathrm{~mL}$ ice-cold phosphoric acid $(85 \% \mathrm{w} / \mathrm{w})$ and stirred at $4{ }^{\circ} \mathrm{C}$ for $18 \mathrm{~h}$. The reaction mix was filled to 2.0 L with cold HQ-water to precipitate cellulose. The precipitate was recovered by vacuum filtration and washed with $2.0 \mathrm{~L}$ of cold HQ-water, $2.0 \mathrm{~L}$ of sodium bicarbonate $(2.0 \mathrm{M})$ and $1.0 \mathrm{~L}$ sodium phosphate buffer (50 mM, pH 6.0). Finally, PASC was diluted with HQ-water and further treated with an Ultra Turrax (Ika, Staufen, GER) to obtain a homogenous solution. Hardwood organosolv lignin (OSL) was prepared from beech (Fagus sp.) wood with a mass average molar mass of $\mathrm{M}_{\mathrm{w}}$ of $10000 \mathrm{~g} \mathrm{~mol}^{-1}$ and a dispersity $\left(Đ, \mathrm{M}_{\mathrm{w}} / \mathrm{M}_{\mathrm{n}}\right.$ ) of 3.1 as reported previously (Zinovyev et al. 2018). Milled Wood Lignin (MWL) from spruce (Picea abies) was prepared as described previously by Björkman with modifications (Björkman 1954; Van Erven et al. 2019). In brief, removal of extractives was achieved by sequential extraction with acetone and water, the resulting-extractive free sample was finely milled in a planetary ball-mill. After water extraction and freeze-drying, extraction of lignin was performed in aqueous dioxane $(80 \% \mathrm{v} / \mathrm{v})$ for $24 \mathrm{~h}$ at room temperature under nitrogen atmosphere twice. Non-soluble material was subsequently separated by centrifugation and the solvent was removed from the lignin sample by freeze-drying.

Enzyme preparation

Celluclast ${ }^{\circledR}$ 1.5L from Novozymes (Cellulase from Trichoderma reesei ATCC 26921) purchased via Sigma Aldrich was used as a commercial enzyme mixture and for the purification of CBHI. The purification procedure was adapted from the published protocol using two consecutive steps of column chromatography (Jäger et al. 2010). For the first step of purification by anion exchange chromatography, $10 \mathrm{~mL}$ Celluclast were rebuffered to $50 \mathrm{mM}$ Tris$\mathrm{HCl}$, pH 7.0 using $60 \mathrm{~mL}$ of Sephadex G-25 Fine (GE Healthcare, Chicago, IL, USA) and the sample was loaded on a $30 \mathrm{~mL}$ DEAE-Sepharose column (XK16, GE Healthcare) equilibrated with the same buffer. Elution was performed stepwise using $35 \%$ and $100 \%$ elution buffer $(200 \mathrm{mM} \mathrm{NaCl}$ in $50 \mathrm{mM}$ Tris- $\mathrm{HCl}, \mathrm{pH}$ 7.0). CBHI eluting at $100 \%$ elution buffer was concentrated using a VivaFlow 50 module with a PES membrane and a molecular weight cut-off (MWCO) of $10 \mathrm{kDa}$ (Sartorius, Goettingen, GER) and was finally purified by size exclusion chromatography using Sephacryl S200 (XK16, 60 cm, GE Healthcare) equilibrated with $10 \mathrm{mM}$ sodium acetate buffer, $\mathrm{pH} 4.8$ applying $0.5 \mathrm{~mL}$ of the concentrated protein solution at a flowrate of $0.5 \mathrm{~mL} \mathrm{~min}^{-1}$. Glyoxal oxidase from Phanerochaete chrysosporium (Wohlschlager et al. 2021b), cellobiose dehydrogenase from $P$. chrysosporium (Wohlschlager et al. 2021a) and laccase from Botrytis aclada (Kittl et al. 2012) were produced and purified as described previously.

Deglycosylation was achieved using $1000 \mathrm{U}$ of Endo Hf (New England Biolabs, MA, USA) per mg of enzyme and incubation at $30{ }^{\circ} \mathrm{C}$ for $18 \mathrm{~h}$ in $50 \mathrm{mM}$ sodium acetate buffer, $\mathrm{pH}$ 6.0. Endo Hf was removed using an MBPTrap HP column (GE Healthcare) equilibrated with binding buffer containing $20 \mathrm{mM}$ Tris-HCl buffer, $\mathrm{pH} 7.4$ containing $200 \mathrm{mM} \mathrm{NaCl}$ and $1 \mathrm{mM}$ EDTA,. The flow-through containing the 
deglycosylated proteins was collected and bound Endo Hf was afterwards eluted in the same buffer supplemented with $10 \mathrm{mM}$ maltose.

All enzyme preparations were rebuffered to $20 \mathrm{mM}$ sodium acetate buffer, $\mathrm{pH} 5.0$ supplemented with $0.05 \%$ Tween 20 using PD 10 desalting columns (GE Healthcare). The purity of the enzyme preparations was evaluated by SDS-PAGE using a 4-20\% MiniPROTEAN ${ }^{\circ}$ TGX stain-free ${ }^{\mathrm{TM}}$ precast gel (BioRad Hercules, CA, USA) and Precision Plus Protein Unstained Standard (BioRad) as ladder for the determination of the molecular weight. Results were evaluated using a Gel Doc XRS + system and Image Lab 6.1 (BioRad) for analysis.

\section{Atomic force microscopy (AFM)}

AFM images of cellulose- and lignin modified surfaces as well as of different intermediate steps of the modification procedure were obtained using a Dimension Icon Scanning Probe Microscope (Nanoscope V, Bruker, Santa Barbara, CA, USA) equipped with a silicon tip on a silicon nitride cantilever (ScanAsyst-Air, Bruker) with a resonance frequency of $70 \mathrm{kHz}$ and a nominal spring constant of $0.4 \mathrm{~N} \mathrm{~m}^{-1}$. Spring constant and deflection sensitivity were calibrated prior imaging in the Bruker software. Topography and Peak Force Error images were obtained in Peak Force Quantitative Nanomechanical Mapping Mode (Peak Force QNM ${ }^{\circledR}$, Bruker) with a scan speed in the range between 0.153 and $0.312 \mathrm{~Hz}$ collecting 256 or 512 pixels per line. Image processing as well as the evaluation of height profiles and surface roughness was performed using Gwyddion 2.56 (Nečas and Klapetek 2012). The raw data was treated with mean plane subtraction and row alignment before the surface roughness was evaluated from at least three image areas $(5 \times 5 \mu \mathrm{m})$.

Determination of static contact angles and surface free energy (SFE)

Static contact angles were measured at $23{ }^{\circ} \mathrm{C}$ and $55 \%$ humidity using a Drop Shape Analyzer DSA 30S (Krüss GmbH, Hamburg, GER). Purified water, ethylene glycol and diiodomethane were used as test liquids. Droplets of $1.0 \mu \mathrm{L}$ were deposited on the surface and images were collected at $10 \mathrm{fps}$ for $2 \mathrm{~s}$. Contact angles were determined using the sessile drop method by fitting the drop shape as ellipse and setting the baseline automatically by the built in software Advance (Krüss). Surface free energy was calculated according to the Owens-Wendt-Rabel-Kaelble (OWRK) method (Owens and Wendt 1969; Kaelble 1970).

\section{Determination of enzymatic activity}

The hydrolytic activity was determined measuring the release of reducing sugars based on the method by Nelson and Somogyi (Nelson 1944; Somogyi 1952). MCC (10 $\left.\mathrm{g} \mathrm{L}^{-1}\right)$, PASC $\left(5 \mathrm{~g} \mathrm{~L}^{-1}\right)$ carboxymethylcellulose (CMC, $\left.10 \mathrm{~g} \mathrm{~L}^{-1}\right)$ and $\alpha$-cellulose $\left(10 \mathrm{~g} \mathrm{~L}^{-1}\right)$ were used as substrates. MCC and PASC were prepared as described previously, CMC sodium salt with a degree of substitution of $0.60-0.95$ was purchased from FLUKA and $\alpha$-cellulose from Sigma-Aldrich. All reactions were performed in $20 \mathrm{mM}$ sodium acetate buffer, $\mathrm{pH}$ 5.0. The substrate was incubated with the enzyme solution in a final volume of $250 \mu \mathrm{L}$ in $2 \mathrm{~mL}$ tubes for $60 \mathrm{~min}$ at $30{ }^{\circ} \mathrm{C}$. Blanks containing only the substrate were prepared equivalently. The reaction was stopped by boiling for $5 \mathrm{~min}$ and the remaining substrate was precipitated by centrifugation at $20238 \times \mathrm{g}$ for $3 \mathrm{~min}$. The clear supernatant $(200 \mu \mathrm{L})$ was mixed with $200 \mu \mathrm{L}$ Somogyi solution and incubated for $20 \mathrm{~min}$ at $99{ }^{\circ} \mathrm{C}$ in the water bath. After cooling, $200 \mu \mathrm{L}$ Nelson solution and $2.3 \mathrm{~mL}$ HQ-water were added. The absorbance at $540 \mathrm{~nm}$ was determined using an Agilent $8453 \mathrm{UV}-$ visible spectrophotometer (Agilent Technologies, Santa Clara, CA, USA) and the concentration of released reducing sugars was calculated using a calibration curve obtained with glucose. One unit was defined as one $\mu$ mol glucose equivalents produced per min under the assay conditions.

\section{Binding studies with MCC and PASC}

Binding of CBHI and Celluclast 1.5L to MCC and PASC was determined in $20 \mathrm{mM}$ sodium acetate buffer, pH 5.0 at $30^{\circ} \mathrm{C}$. Different concentrations of CBHI $(1-50 \mu \mathrm{M})$ were incubated with $10 \mathrm{mg} \mathrm{mL}^{-1}$ MCC (particle size $<45 \mu \mathrm{m}$ ) or $1.25 \mathrm{mg} \mathrm{mL}^{-1}$ PASC in a thermomixer at $800 \mathrm{rpm}$ for $30 \mathrm{~min}$ and the enzyme bound to the substrate was removed by centrifugation at $20238 \times \mathrm{g}$ for $3 \mathrm{~min}$. For purified $\mathrm{CBHI}$ the concentration of remaining enzyme in the 
supernatant was determined spectrophotometrically measuring the absorbance at $280 \mathrm{~nm}$ using an Agilent 8453 UV-visible spectrophotometer. The dissociation constant $\left(K_{D}\right)$ and maximum binding capacity $\left(B_{\max }\right)$ was calculated by fitting the data to a hyperbolic function using Sigma Plot 14.0 (Systat Software Inc., San Jose, CA, USA).

Preparation of cellulose and lignin films

The procedure for the dissolution of cellulose in N,Ndimethylacetamide (DMAc) and the preparation of homogenous cellulose films was adapted from previously published procedures (Raj et al. 2012; Sczech and Riegler 2006). In brief, MCC was swollen in HQwater constantly stirred at $22{ }^{\circ} \mathrm{C}$ for $18 \mathrm{~h}$ and further incubated in methanol for $45 \mathrm{~min}$ at $40{ }^{\circ} \mathrm{C}$ twice. The material was treated with DMAc at $22{ }^{\circ} \mathrm{C}$ for $45 \mathrm{~min}$ for four times. Activated cellulose was finally dried at $60{ }^{\circ} \mathrm{C}$ under vacuum for $24 \mathrm{~h}$ and dissolution was performed using anhydrous DMAc containing 7\% (w/ w) water free $\mathrm{LiCl}$ under constant stirring at $40{ }^{\circ} \mathrm{C}$ for $18 \mathrm{~h}$.

Cellulose films on SPR probes were produced as previously described using the SIA Kit Au (GE Healthcare) (Laurent et al. 2019). The gold surface was cleaned with alkaline Piranha solution $\left(\mathrm{NH}_{4} \mathrm{OH} /\right.$ $\mathrm{H}_{2} \mathrm{O}_{2} / \mathrm{H}_{2} \mathrm{O}, 1: 1: 3$ ) at $75{ }^{\circ} \mathrm{C}$ for $15 \mathrm{~min}$, washed with HQ-water and dried at $80{ }^{\circ} \mathrm{C}$. The surface was then pretreated with $100 \mathrm{mg} \mathrm{L}^{-1}$ poly(diallyldimethylammoniumchloride) (PDADMAC, Sigma Aldrich) as adhesion promoter supplemented with $10 \mathrm{mM} \mathrm{NaCl}$ for $30 \mathrm{~min}$. After washing in HQ-water and drying, activated cellulose was deposited by spin coating using $80 \mu \mathrm{L}$ of $0.5(\mathrm{w} / \mathrm{w})$ cellulose in $\mathrm{DMAc} / \mathrm{LiCl}$ at $3000 \mathrm{rpm}$ for $3 \mathrm{~min}$. The solvent was removed by drying at $160{ }^{\circ} \mathrm{C}$ and the resulting cellulose film was washed extensively in $\mathrm{HQ}$-water to remove $\mathrm{LiCl}$. Finally, the modified gold surface was dried at $160{ }^{\circ} \mathrm{C}$ and stored at room temperature in the desiccator over silica.

The preparation of lignin films using OSL from beech wood or MWL from spruce was adapted from a published procedure (Pereira et al. 2017). The lignin preparations were dissolved to a final concentration of $0.5 \%(w / w)$ in 1,4-dioxane/water $(96: 4, \mathrm{v} / \mathrm{v})$ under rotary shaking at $22{ }^{\circ} \mathrm{C}$ for $24 \mathrm{~h}$. The gold surface was cleaned as described previously and modified with $0.5 \%$ (w/v) polystyrene (PS, average Mw 35000 ,
Sigma Aldrich) dissolved in toluene by spin coating at $2000 \mathrm{rpm}$ for $30 \mathrm{~s}$. Lignin was deposited 8 times using the same conditions for spin coating and the layer was dried at $80{ }^{\circ} \mathrm{C}$ for $30 \mathrm{~min}$ between each step. The modified SPR probe was stored at room temperature in a desiccator over silica under nitrogen atmosphere until further use.

SPR measurements

The SPR probe was assembled according to the instructions of the manufacturer. SPR measurements were performed using a Biacore T200 system (GE Healthcare) with $20 \mathrm{mM}$ sodium acetate buffer, $\mathrm{pH}$ 5.0 supplemented with $0.05 \%$ (w/w) Tween 20 used as running buffer. Experiments were performed at $30{ }^{\circ} \mathrm{C}$ with a flow rate of $10 \mu \mathrm{L} \mathrm{min}{ }^{-1}$ and for the regeneration of the sensor surface a $5 \mathrm{M}$ sodium chloride solution for $60 \mathrm{~s}$ and a $10 \mathrm{mM}$ glycine $/ \mathrm{HCl}$ buffer, $\mathrm{pH} 2.0$ for $30 \mathrm{~s}$ at the same flow rate was used. For the initial equilibration of the surface, three cycles of blank injections with running buffer followed by regeneration of the sensor surface was performed. The equilibration was performed to guarantee for a stable baseline during the measurements and to avoid effects caused by ongoing swelling of the sensor surface or other surface rearrangements. Binding kinetics using cellulose were determined by singlecycle-kinetic (SCK) measurements with five sequential injections of the analyte with an association period of $60 \mathrm{~s}$ and a final dissociation period of $180 \mathrm{~s}$ without regeneration between the injections of one cycle. Binding to lignin surfaces was investigated by multicycle-kinetic (MCK) measurements with an association period of $120 \mathrm{~s}$ and a dissociation period of $180 \mathrm{~s}$. All samples were rebuffered using PD-10 desalting columns (Sephadex G-25 M, GE Healthcare) and diluted in running buffer to avoid differences in refractive index of the solvent. Data were evaluated using the BiaEvaluation Software version 3.1 (GE Healthcare) and SigmaPlot version 12.0.

The thickness (d) of the adsorbed film was estimated according the method by Jung et al. from the SPR response $\mathrm{R}$ evaluating the slope $\mathrm{m}$ obtained from a calibration curve using glycerol solutions with known refractive index (Fig. S5) and the difference between the refractive index of the adsorbed layer $\left(\eta_{\mathrm{a}}\right)$ and the refractive index of the solvent $\left(\eta_{\mathrm{S}}\right)$ (Eq. 1) (Jung et al. 1998; Pereira et al. 2017; Salas et al. 2013). 
$\mathrm{d}=\frac{l_{d}}{2} \frac{R}{m \cdot\left(\eta_{a}-\eta_{S}\right)}$

The characteristic decay length of the evanescent wave $\left(l_{d}\right)$ was approximated as 0.37 times the light wavelength, the refractive indices for cellulose, lignin, the adsorbed protein layer, and the bulk fluid were estimated as $1.47,1.61,1.44$, and 1.333 , respectively (Jung et al. 1998; Vörös 2004; Norgren et al. 2006; Kasarova et al. 2007) (Fig. S5).

The surface loading $(\Gamma)$ was calculated using the density $(\rho)$ of the adsorbed layer with $\rho$ of cellulose assumed as $1.60 \mathrm{~g} \mathrm{~cm}^{-3}$ and lignin as $1.30 \mathrm{~g} \mathrm{~cm}^{-3}$ (Eq. 2, Daicho et al. 2020; Triwulandari et al. 2019). For the calculation, the densities reported for dry and homogenous compounds were used. The density of the adsorbed protein was estimated as $1.32 \mathrm{~g} \mathrm{~cm}^{-3}$ according to Eq. 3 using the molecular weight (M), the volume of the protein $(\mathrm{V})$ in $\AA^{3}$ and Avogadro's number $\left(\mathrm{N}_{\mathrm{A}}\right)$ (Quillin and Matthews 2000).

$\Gamma=\mathrm{d} \rho$

$\rho=\frac{10^{24} M}{V N_{A}}$

A model of the full-length CBHI obtained with SWISS-MODEL (https://swissmodel.expasy.org/) using the structures of the catalytic domain (pdb: 7CEL) and its CBM (pdb: $5 \times 34$ ) as template was used to calculate the molecular volume according to the Voronoi procedure applying VADAR Version 1.8 (Willard et al. 2003).

\section{Results and discussion}

Characterisation of cellulose and lignin films

Cellulose films from MCC dissolved in DMAc/LiCl and lignin films using MWL (spruce) or OSL (beech) dissolved in dioxane/water were prepared by spincoating. MWL and OSL from softwood and hardwood respectively were chosen to represent lignin preparations with different characteristics. While MWL from spruce is almost exclusively composed of G-units and the extraction procedure prevents extensive alterations of the naturally occurring lignin, OSL from beech wood is composed of mainly S and G-units and is substantially modified and condensed during the extraction.

Initial experiments were performed using glass slides to optimize the spin-coating time, angular velocity, and substrate concentration for the preparation of homogenous films. Based on the optimized parameters, films were prepared on SPR probes. Prior to the modification with the substrate, the surface was modified with polycationic PDADMAC for cellulose films or with polystyrene (PS) for lignin films to promote adhesion. The different steps of modification and the final films were analysed by AFM imaging (Fig. S1). All films on SPR probes were shown to be homogenous and to cover the entire measurement area (Fig. 1). The root mean square (RMS) roughness measured from at least three areas with a size of 25 $\mu \mathrm{m}^{2}$ was calculated and showed that the roughness of the cleaned glass or gold surface increased when modified with PDADMAC or PS (Table 1). Modification of surfaces with cellulose or lignin resulted in a further increase of roughness to $5.60 \pm 1.54 \mathrm{~nm}$ for cellulose, $4.44 \pm 0.01 \mathrm{~nm}$ for OSL and $8.30 \pm 1.72 \mathrm{~nm}$ for MWL on the SPR probes. The RMS roughness of the cellulose surface is comparable to that reported for cellulose films regenerated from cellulose xanthate with 4.99 to $5.17 \mathrm{~nm}$ (Weißl et al. 2018) or films prepared from cellulose dissolved in DMAc with $4.8 \mathrm{~nm}$ (Table S1) (Eriksson et al. 2005a). Spherical aggregates were visible in the AFM images of the lignin films as observed in prior studies using MWL from different sources and Kraft lignin for the preparation of artificial lignin films. (Norgren et al. 2006; Notley and Norgren 2010; Pereira et al. 2017) Although the observed RMS roughness is slightly higher than observed in the cited studies, the distribution of nanoscale particles appeared uniform and the film covered the underlying surface homogenously.

To characterize the hydrophobicity and wettability of the films, contact angle measurements were performed using water, ethylene glycol, or diiodomethane as testing liquids. SPR probes modified with cellulose showed a static contact angle of $30.5^{\circ} \pm 0.1^{\circ}$ and $45.1^{\circ} \pm 0.2^{\circ}$ with water and diiodo-methane, respectively, which is consistent with the values reported for cellulose films produced using $\mathrm{DMAc} / \mathrm{LiCl}$ as solvent, regenerated from cellulose xanthate or trimethylsilyl cellulose (Eriksson et al. 2005a; Sczech and Riegler 2006; Mohan et al. 2011; Weiß1 et al. 2018). For cellulose-modified gold and 
(a)

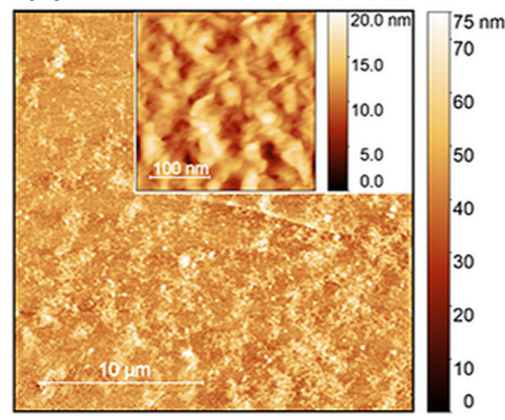

(b)

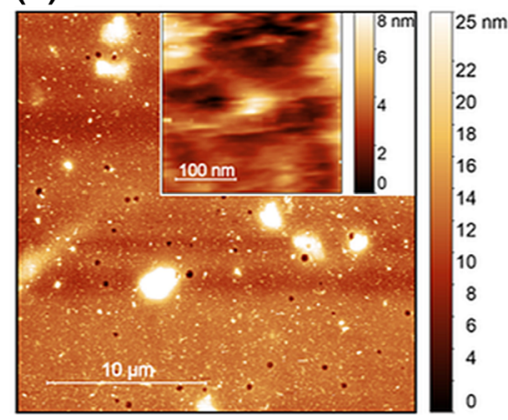

(c)

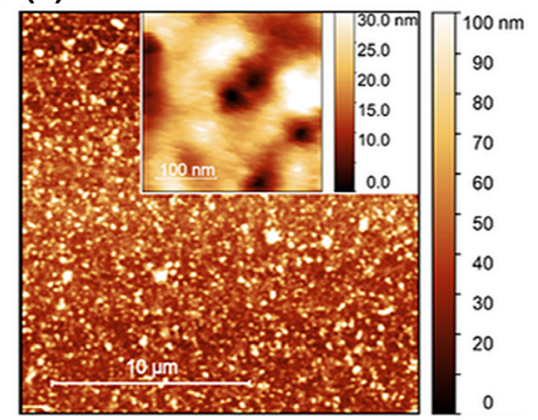

Fig. 1 AFM images of dry cellulose (a), MWL (b) and OSL (c) films prepared on the gold surface of SPR probes. Scale bars represent $10 \mu \mathrm{m}$ in main images and $100 \mathrm{~nm}$ in insets

Table 1 Static contact angles and surface roughness of modified and non-modified gold and glass surfaces. Surface roughness was calculated from AFM images using Gwyddeon
2.56. Data represent mean values and standard deviations of at least three areas $(5 \times 5 \mu \mathrm{m})$

\begin{tabular}{|c|c|c|c|c|c|c|}
\hline \multirow[t]{2}{*}{ Surface } & \multirow[t]{2}{*}{ Modification } & \multicolumn{3}{|c|}{ Static contact angle [deg] } & \multicolumn{2}{|l|}{ Surface roughness [nm] } \\
\hline & & Water & Ethylenglycol & Diiodo-methane & RMS roughness $(\mathrm{Sq})$ & Mean roughness $(\mathrm{Sa})$ \\
\hline \multirow[t]{6}{*}{ Gold } & None & $89.9 \pm 0.3$ & $64.8 \pm 0.4$ & $60.4 \pm 0.2$ & $0.39 \pm 0.02$ & $0.31 \pm 0.01$ \\
\hline & PDADMAc & $70.3 \pm 4.9$ & $49.1 \pm 0.2$ & $47.6 \pm 0.2$ & $1.68 \pm 0.08$ & $1.20 \pm 0.07$ \\
\hline & PS & $103.5 \pm 0.6$ & $76.8 \pm 1.6$ & $18.7 \pm 2.3$ & $2.33 \pm 0.62$ & $0.99 \pm 0.18$ \\
\hline & OSL & $67.6 \pm 0.6$ & $37.9 \pm 3.7$ & $34.2 \pm 0.1$ & $4.44 \pm 0.01$ & $3.26 \pm 0.07$ \\
\hline & MWL & $68.3 \pm 1.2$ & $43.4 \pm 1.7$ & $41.6 \pm 0.1$ & $8.30 \pm 1.72$ & $2.80 \pm 0.21$ \\
\hline & Cellulose & $30.5 \pm 0.1$ & $16.2 \pm 20.9$ & $45.1 \pm 0.2$ & $5.60 \pm 1.54$ & $3.91 \pm 0.90$ \\
\hline \multirow[t]{6}{*}{ Glass } & None & $72.1 \pm 0.8$ & $63.1 \pm 0.1$ & $64.8 \pm 0.3$ & $0.80 \pm 0.14$ & $0.51 \pm 0.07$ \\
\hline & PDADMAc & $58.3 \pm 0.1$ & $44.5 \pm 0.4$ & $48.3 \pm 0.2$ & $2.13 \pm 0.39$ & $1.03 \pm 0.09$ \\
\hline & PS & $90.5 \pm 0.1$ & $68.3 \pm 0.2$ & $14.9 \pm 3.4$ & $1.29 \pm 0.01$ & $0.85 \pm 0.01$ \\
\hline & OSL & $64.0 \pm 0.9$ & $40.3 \pm 3.2$ & $39.6 \pm 0.1$ & n.d & n.d \\
\hline & MWL & $62.2 \pm 1.0$ & $38.8 \pm 2.1$ & $37.2 \pm 0.2$ & n.d & n.d \\
\hline & Cellulose & $30.0 \pm 0.4$ & $23.2 \pm 3.7$ & $43.3 \pm 0.1$ & $5.42 \pm 1.15$ & $4.19 \pm 0.90$ \\
\hline
\end{tabular}

glass surface, similar contact angles were observed. The water contact angles determined for OSL and MWL were $67.6^{\circ} \pm 0.6^{\circ}$ and $68.3^{\circ} \pm 1.2^{\circ}$, respectively, and are in excellent agreement with the values $\left(66-69^{\circ}\right)$ reported for MWL from different sources for the preparation of thin films on gold (Pereira et al. 2017). For OSL prepared from beech wood a slightly lower water contact angle of $58^{\circ} \pm 1^{\circ}$ was determined on PS-coated silicon wafers (Borrega et al. 2020). Thin films prepared from Kraft lignin were shown to result in even lower contact angles highlighting the importance of the performed lignin extraction process for the characteristics of the resulting film (Norgren et al. 2006).
The polar and dispersive components of the surface free energy (SFE) were calculated according to the Owens-Wendt-Rabel-Kaelble model (Fig. 2). The SFE of the gold or glass surfaces increases when treated with PDADMAC or PS and is further increased by the final modification with cellulose or lignin. While the total SFE of the lignin films is predominantly determined by the disperse component, for the cellulose film the polar component is almost equal. The values determined within this study are in the range of previous works and indicate a hydrophilic surface of the cellulose film (Table SI 1) (Eriksson et al. 2007; Notley and Norgren 2010; Weiß1 et al. 2018). 
(a)

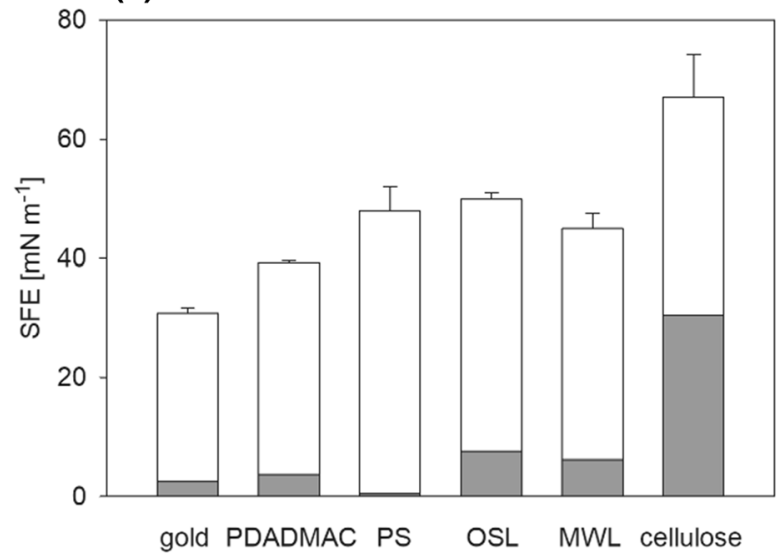

(b)

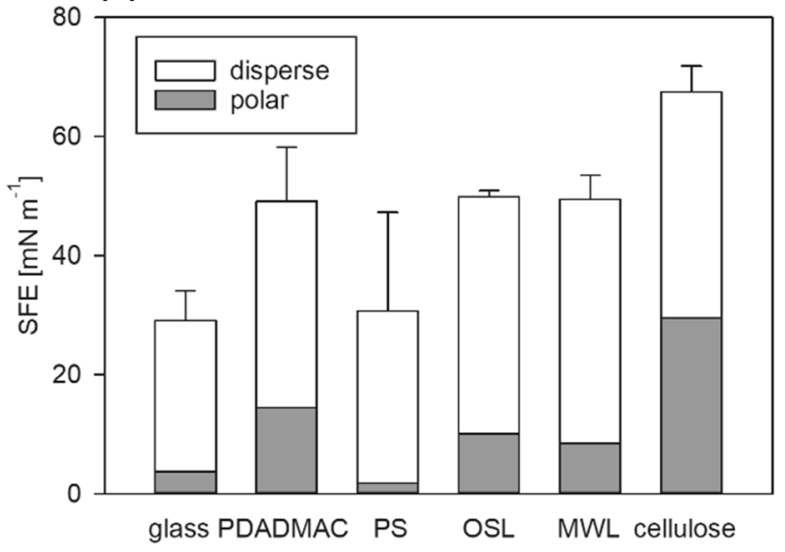

Fig. 2 Sum of surface free energy from disperse and polar contributions for cellulose and lignin films prepared on gold (a) and glass (b) surfaces

Hydrolytic activity with different cellulosic model substrates

Celluclast and purified CBHI were deglycosylated using Endo Hf and the enzyme used for deglycosylation was subsequently removed using an MBPTrap column. The homogeneity of the enzyme preparation and the successful removal of Endo Hf were demonstrated by SDS-PAGE. (Fig. S2) The activity of untreated and deglycosylated enzyme preparations were assayed by the release of reducing sugars from different model substrates and quantified by the method of Nelson and Somogyi using a calibration curve obtained with D-glucose (Fig. S3). With each enzyme preparation, the highest activity was found

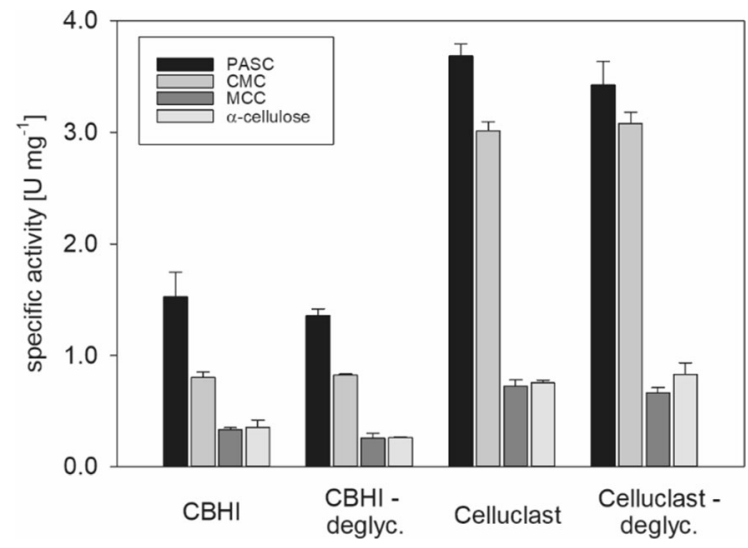

Fig. 3 Comparison of cellulose hydrolysis in solution by CBHI and Celluclast before and after deglycosylation with Endo $\mathrm{Hf}$ using PASC, CMC, MCC and $\alpha$-cellulose as substrates using PASC as substrate while the activity observed with MCC and $\alpha$-cellulose was lower by a factor of 4.6 and 5.2, respectively (Fig. 3). This difference in hydrolytic activity shows the large influence of cellulose crystallinity on its efficient enzymatic degradation (Percival Zhang et al. 2006; Hall et al. 2010). The yield of reducing sugars using Celluclast exceeded that of purified CBHI by a factor of 2.1-2.6 with the model substrates PASC, MCC, and $\alpha$ cellulose. For CMC a 3.7-3.8 higher activity could be observed using Celluclast compared to isolated CBHI. This high difference in specific activity can be explained by the good susceptibility of this substrate for degradation by EGs (Claeyssens and Aerts 1992). No significant difference in hydrolytic activity could be detected between the deglycosylated and untreated enzyme preparations. The results demonstrate that the $\mathrm{N}$-glycosylation of CBHI is not influencing enzyme activity and that the enzymes maintain sufficient stability upon removal of N-linked glycans under the chosen reaction conditions in these experiments $\left(30{ }^{\circ} \mathrm{C}, 1000 \mathrm{rpm}, 60 \mathrm{~min}\right)$.

Binding studies and adsorption isotherms

Substrate binding is a crucial, potentially rate limiting step of enzyme catalysis. Binding experiments of the untreated and deglycosylated CBHI in solution were performed with amorphous PASC and MCC to study the influence of $\mathrm{N}$-glycans on substrate binding (Fig. 4). All reactions were incubated for $30 \mathrm{~min}$ to 
(a)

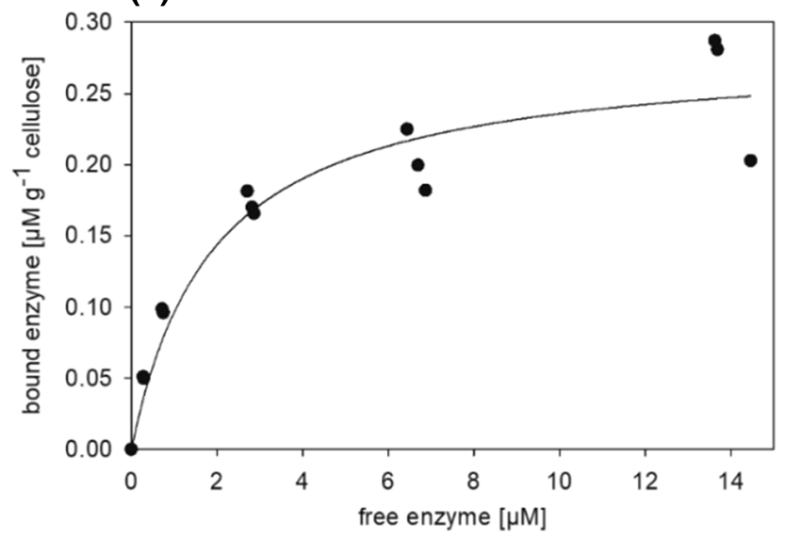

(c)

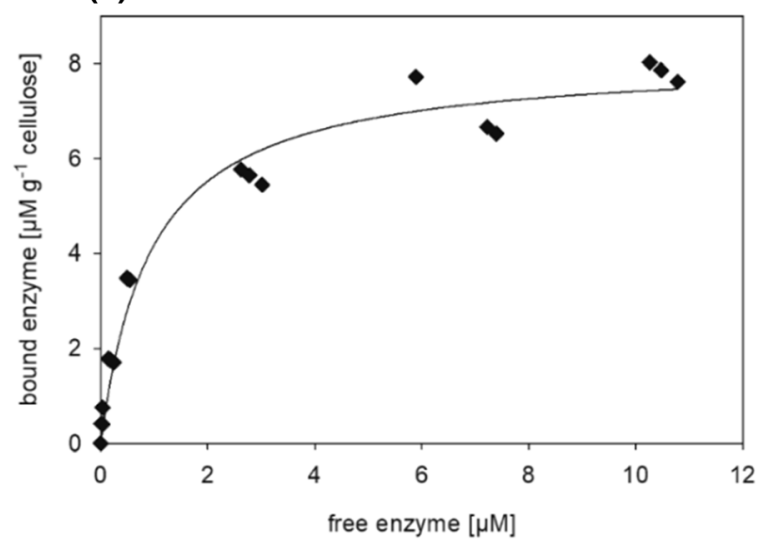

(b)

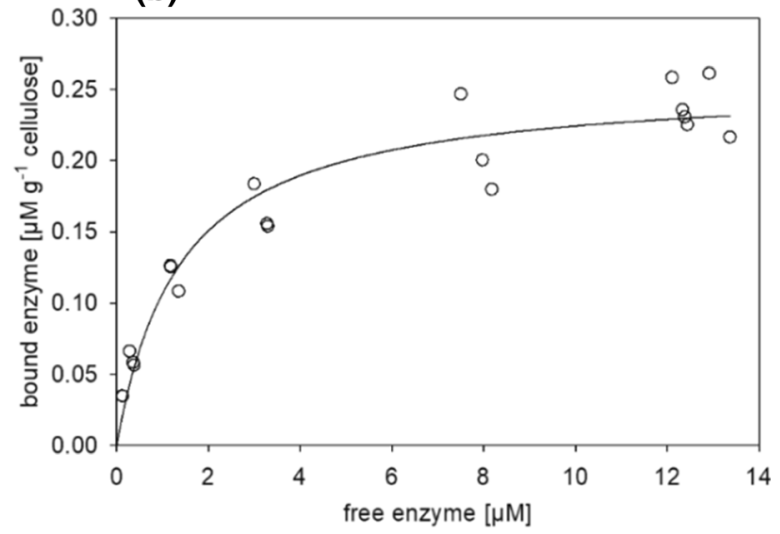

(d)

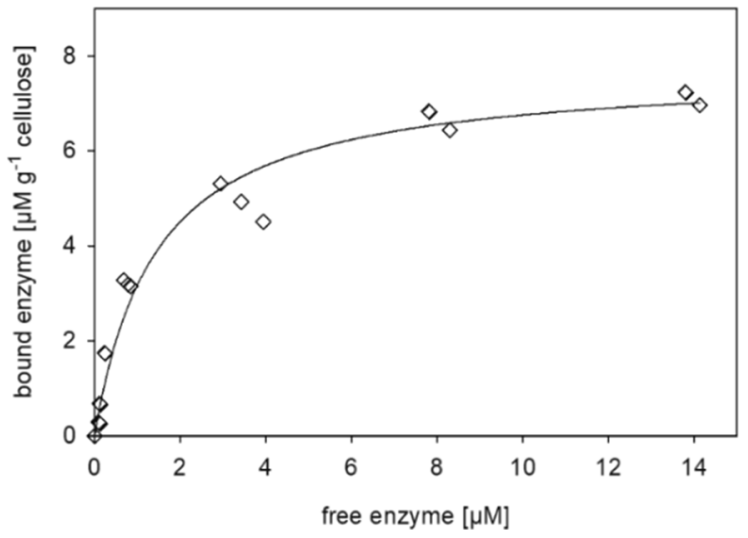

Fig. 4 Binding of untreated CBHI to MCC (a) and PASC (c) compared to the Endo Hf treated, deglycosylated CBHI binding to MCC (b) and PASC (d). Data were fitted according to the Langmuir model to a hyperbolic equation using SigmaPlot 14.0

reach the binding equilibrium and to avoid excessive substrate degradation. Data were fitted according tothe Langmuir model to a hyperbolic function with $B_{\max }$ being the maximum binding capacity at equilibrium conditions, $K_{\mathrm{D}}$ representing the dissociation constant, and $[\mathrm{E}]$ the concentration of enzyme (Eq. 4).

$[\mathrm{E}]_{\text {adsorbed }}=\frac{B_{\max } *[\mathrm{E}]}{K_{\mathrm{D}}+[\mathrm{E}]}$

While the dissociation constant of CBHI for PASC slightly increased from $0.94 \pm 0.17$ to $1.43 \pm 0.25 \mu \mathrm{M}$ upon deglycosylation, no significant difference between the $K_{\mathrm{D}}$ and $B_{\max }$ was observed between the untreated and deglycosylated CBHI using MCC (Table 2). Henriksson et al. reported a slightly higher $K_{\mathrm{D}}$ of $\mathrm{CBHI}$ for MCC of $3.6 \mu \mathrm{M}$. However, those measurements were performed at a $5{ }^{\circ} \mathrm{C}$ lower temperature and in $50 \mathrm{mM}$ ammonium acetate buffer,
pH 5.0, compared to $20 \mathrm{mM}$ sodium acetate buffer, $\mathrm{pH}$ 5.0, used in our study (Henriksson et al. 1997).

The binding of CBHI to cellulose is a complex process influenced on the one hand by the heterogeneity of the substrate considering the differences between crystalline and amorphous regions as well as degree of polymerization and accessibility of chain ends, and on the other hand by the molecular architecture of the enzyme consisting of a catalytic domain and a CBM connected by a flexible linker. A variety of different binding models have been proposed including the Freundlich model, combined Langmuir-Freundlich models, the Hill cooperative binding model, and others to describe enzyme adsorption and binding to the substrate (Jalak and Väljamäe 2014). In our study, a reasonable fit with $R^{2}$ values of 0.9-0.96 was obtained using the standard Langmuir binding model. 
SPR measurements to study cellulase binding to cellulose and lignin films

First, a method for the regeneration of the SPR probe film surface had to be developed to remove bound protein of previous measurements from the lignin or cellulose films. Different approaches including high ionic strength (5 M NaCl or $4 \mathrm{M} \mathrm{MgCl}$ ), low $\mathrm{pH}$ (10 mM glycine $\mathrm{HCl}, \mathrm{pH} 2.0)$, high $\mathrm{pH}(10 \mathrm{mM}$ $\mathrm{NaOH})$, and the use of a detergent $(0.5 \%$ SDS) were tested. The test was performed using a set of different cellulolytic enzymes as well as enzymes involved in lignin degradation. Therefore, CBHI, glyoxal oxidase, pyranose 2-oxidase, laccase and cellobiose dehydrogenase were used for initial testing procedures. The best results were obtained by using a two-step procedure with $5 \mathrm{M} \mathrm{NaCl}$ followed by $10 \mathrm{mM}$ glycine $\mathrm{HCl} \mathrm{pH} 2.0$ with a contact time of $30 \mathrm{~s}$, which was then employed to regenerate the SPR probe after each measurement.

The thickness of the cellulose and lignin films was determined by AFM by carefully removing part of the film with a razor blade and measuring the height difference between the modified and unmodified surface (Fig. S4). Furthermore, the thickness of the cellulose or lignin films was calculated from the SPR data from the average of the signal from four flow channels according to Eqs. 1 and2 (Table 3). A calibration curve was determined using different concentrations of glycerol with known refractive indices (Fig. S5).

The thickness of the lignin-modified surfaces found by AFM were $23.2 \mathrm{~nm}$ and $14.6 \mathrm{~nm}$ for OSL and MWL, respectively, and are higher than the values obtained from SPR measurements. This could possibly be explained by the removal of not tightly bound lignin residues from the SPR probe film surface during the initial equilibration in running buffer and regeneration. The OSL films were slightly thicker than the MWL films. Film thickness as well as roughness potentially depend on the size distribution of lignin fragments, their composition, and their degree of branching. Pereira et al. observed that films prepared from spruce or wheat straw lignin appeared rougher and from spruce also thicker than films from eucalyptus wood, putatively because of the higher amount of syringyl-residues in eucalyptus lignin. Therefore, more linear structures and less branching is found in this type of lignin influencing the resulting films to be smoother (Pereira et al. 2017). In our study, the differences in thickness and roughness between the two types of lignin can also be explained by the feedstock and different extraction and pretreatment procedures. Cellulose showed a thickness of $24.9 \mathrm{~nm}$ when measured by AFM while a value of $36.4 \mathrm{~nm}$ was calculated from the SPR response. The values of the dry cellulose films determined by AFM are in good agreement with previous studies reporting $28 \mathrm{~nm}$ and $30 \mathrm{~nm}$ thick cellulose films in the dry state using a similar procedure (Eriksson et al. 2005a, 2005b).

The higher value obtained by SPR data could reflect the swelling of the cellulose film when exposed to the aqueous buffer. However, a precise quantification of the degree of swelling is not feasible by comparing data obtained by AFM and SPR measurements because of the limited comparability of the values obtained using different methods for the determination of film thicknesses in the nano-scale (Sczech and Riegler 2006).

Swelling of cellulose films prepared by spin coating techniques using different solvents has been reported and was shown to be more pronounced for amorphous films produced using $\mathrm{DMAc} / \mathrm{LiCl}$. Using quartz crystal microbalance measurements Aulin et al. determined the mass of adsorbed water in the cellulose film prepared from $\mathrm{DMAc} / \mathrm{LiCl}$ as $48 \%$ of the swollen film

Table 2 Dissociation constants $\left(K_{\mathrm{D}}\right)$ and maximum binding capacity $\left(B_{\max }\right)$ of glycosylated and deglycosylated CBHI evaluated by using the Langmuir equation

\begin{tabular}{lllll}
\hline Enzyme preparation & Substrate & $K_{\mathrm{D}}[\mu \mathrm{M}]$ & $B_{\max }\left[\mu \mathrm{mol} \mathrm{g}{ }^{-1}\right.$ cellulose $]$ & 0.96 \\
\hline Untreated CBHI & PASC & $0.94 \pm 0.17$ & $8.11 \pm 0.36$ & 0.90 \\
& MCC & $1.91 \pm 0.58$ & $0.28 \pm 0.02$ & 0.96 \\
Deglycosylated CBHI & PASC & $1.43 \pm 0.25$ & $7.72 \pm 0.35$ & 0.96 \\
\hline
\end{tabular}


Table 3 Evaluation of film thickness from SPR measurements and AFM imaging. The thicknesses were calculated according to Eq. 2 estimating the densities and refractive indices of lignin and cellulose the as reported previously. The refractive index of the buffer solvent was calculated to be 1.334

\begin{tabular}{lllllll}
\hline & \multicolumn{2}{l}{ SPR } & & & AFM \\
\cline { 2 - 5 } & $\begin{array}{l}\text { Response } \\
\text { units[RU] }\end{array}$ & $\begin{array}{l}\text { Refractive } \\
\text { index }\end{array}$ & $\begin{array}{l}\text { Density[g } \\
\left.\mathrm{cm}^{-3}\right]\end{array}$ & $\begin{array}{l}\text { Adsorbed mass[mg } \\
\left.\mathrm{m}^{-2}\right]\end{array}$ & $\begin{array}{l}\text { Film thickness } \\
{[\mathrm{nm}]}\end{array}$ & $\begin{array}{l}\text { Film thickness } \\
{[\mathrm{nm}]}\end{array}$ \\
\hline OSL & $22690 \pm 1320$ & $1.61^{(1)}$ & $1.30^{(3)}$ & $22.6 \pm 1.3$ & $17.4 \pm 1.0$ & $23.2 \pm 4.0$ \\
MWL & $17660 \pm 1170$ & $1.61^{(1)}$ & $1.30^{(3)}$ & $15.4 \pm 1.0$ & $11.8 \pm 0.8$ & $14.6 \pm 2.4$ \\
Cellulose & $24890 \pm 2670$ & $1.47^{(2)}$ & $1.60^{(4)}$ & $58.2 \pm 6.2$ & $36.4 \pm 3.9$ & $24.9 \pm 6.1$ \\
\hline
\end{tabular}

\footnotetext{
${ }^{(1)}$ (Norgren et al. 2006)

(2)(Kasarova et al. 2007)

${ }^{(3)}$ (Triwulandari et al. 2019)

${ }^{\text {(4) }}$ (Daicho et al. 2020)
}

(Aulin et al. 2009). Another study reports even more pronounced swelling behavior deduced from the observed decrease in the refractive indices upon buffer exposition resulting in an increase in the film thickness by a factor of 2.5 (Eriksson et al. 2005a).

The regeneration of cellulose from $\mathrm{DMAc} / \mathrm{LiCl}$ results in the formation of mainly amorphous cellulose and only a minor proportion of cellulose II (Aulin et al. 2009). Despite this difference to cellulose found naturally in the plant cell wall, cellulolytic enzymes within Celluclast as well as isolated cellobiohydrolases or endoglucanases have been shown to be capable of the degradation of artificial cellulose films (Eriksson et al. 2005a; Josefsson et al. 2008; Suchy et al. 2011). In particular, endoglucanases have been shown to degrade amorphous cellulose films efficiently and cause pronounced swelling of the model film as demonstrated by quartz crystal microbalance measurements (Suchy et al. 2011). To reduce the total contact time and to avoid fast removal of the film upon exposure to the enzymes, the binding studies with cellulose were performed as single cycle kinetic (SCK) measurements. This technique has been used to study binding of lytic polysaccharide monooxygenase (LPMO) to cellulosic surfaces and to investigate the role of the CBM (Laurent et al. 2019). No significant difference between the untreated and the deglycosylated CBHI was observed by SPR measurements showing that the removal of $\mathrm{N}$-glycans does only slightly affect substrate binding (Fig. 5). Furthermore, no significant difference between the $K_{\mathrm{D}}$ values of different enzyme preparations was observed, which is in good agreement with the data obtained from the binding studies using PASC and MCC. The maximal surface loading was calculated as $1.8 \mathrm{mg} \mathrm{m}^{-2}$ for the untreated and $1.7 \mathrm{mg} \mathrm{m}^{-2}$ for the deglycosylated CBHI (Table 4).

The surface properties and hydrophobicity of lignocellulolytic enzymes is crucial for their tendency to adsorption to lignin. Although some reports also highlight ionic interaction and hydrogen bonding that can contribute to binding to lignin, this undesired interaction is suggested to be caused mainly by hydrophobic interactions. CBHI has been shown to have a higher affinity to lignin than xylanases, EGs and $\beta$-glucosidases and especially the CBM is thought to contribute to this undesired non-productive binding to the lignin fraction of plant biomass (Berlin et al. 2006; Guo et al. 2014). Investigations based on NMR measurements using the isolated CBM of CBHI and artificial lignin oligomers verified the strong interactions between mainly of tyrosine residues of the CBM and the aromatic lignin by hydrophobic interactions as well as $\pi-\pi$ stacking (Tokunaga et al. 2020).

A factor that modulates the solubility and hydrophobicity of enzymes is the posttranslational modification with glycosides. Within the amino acid sequence of CBHI from T. reesei four Asn-Xaa-(Ser/ Thr) sequons-Asn45, Asn64, Asn270 and Asn384could be potential sites of N-glycosylation. Applying capillary liquid chromatography coupled electrospray mass spectrometry (cLC-ESMS), Hui et al. found that only Asn 270 harbours a high-mannose type glycan while Asn 45 and Asn 384 are only modified with single 
(a)

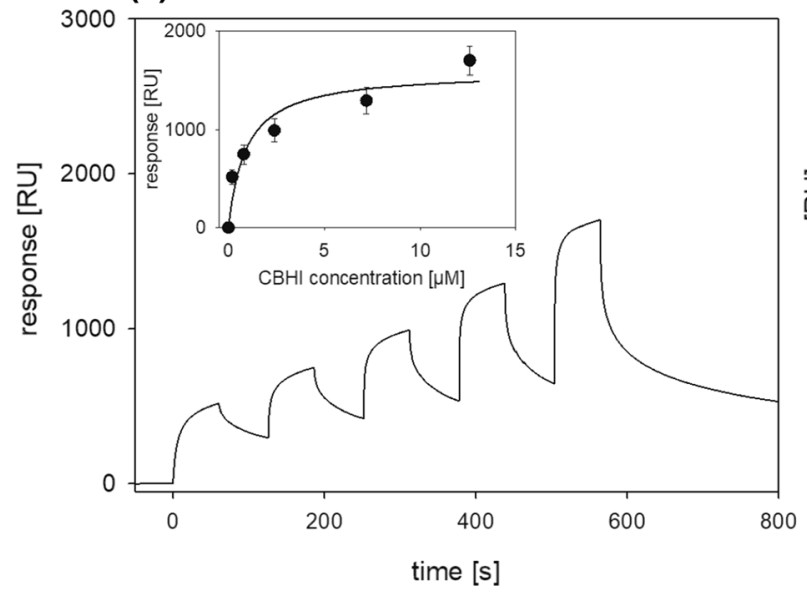

Fig. 5 Binding of CBHI (a) and deglycosylated CBHI (b) to cellulose films was performed as single cycle kinetic (SCK) experiment with five injections of increasing enzyme concentration $(0.2 \mu \mathrm{M}, 0.8 \mu \mathrm{M}, 2.4 \mu \mathrm{M}, 7.2 \mu \mathrm{M}$ and $12.6 \mu \mathrm{M})$. From (b)

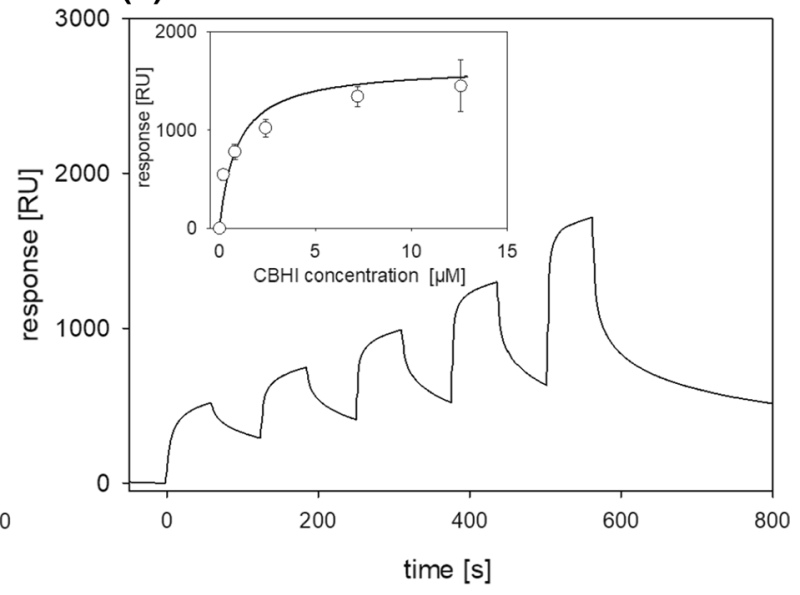

the six performed measurements using two flow channels an averaged sensogram was calculated, the data in the inset are averaged from all six measurements

Table 4 Apparent dissociation constants $\left(K_{\mathrm{D}}\right)$ and maximal surface loading $\left(\Gamma_{\max }\right)$ determined by SPR on cellulose. The density of the adsorbed protein layer and the refractive index were estimated as $1.32 \mathrm{~g} \mathrm{~cm}^{-3}$ and 1.57 , respectively

\begin{tabular}{llll}
\hline Enzyme preparation & $K_{\mathrm{D}}[\mu \mathrm{M}]$ & $\mathrm{R}_{\max }[\mathrm{RU}]$ & $\Gamma_{\max }\left[\mathrm{mg}\right.$ enzyme $\left.\mathrm{m}^{-2}\right]$ \\
\hline Untreated CBHI & $0.91 \pm 0.17$ & $1611 \pm 68$ & $1.82 \pm 0.04$ \\
Deglycosylated CBHI & $0.78 \pm 0.15$ & $1528 \pm 70$ & $1.72 \pm 0.05$ \\
\hline
\end{tabular}

GlcNAc moieties. A large variability and heterogeneity in the N-glycosylation patterns of Cel7A is reported which is proposed to depend on the fungal strains and cultivation processes influencing the level of endoglucosidase $\mathrm{H}$ or endoglucosidase $\mathrm{F}$ activity in the culture fluid. Additionally, Ser and Thr residues found in the linker region between the catalytic core region and the CBM were shown to be heterogeneously O-glycosylated (Klarskov et al. 1997; Hui et al. 2001; Stals et al. 2004; Amore et al. 2017). Although some reports based on the results of site directed mutagenesis studies targeting the $\mathrm{N}$-glycosylation sites of $\mathrm{CBHI}$ from $T$. reesei point out that $\mathrm{N}$-glycosylation is important for its thermal stability (Qi et al. 2014; Amore et al. 2017) and the presence of large glycans at the catalytic domain interferes with cellulose binding and catalytic processivity (Jeoh et al. 2008; Adney et al. 2009), the results are not completely conclusive. Amore et al. further highlighted the importance of $\mathrm{N}$-glycosylation as well as O-glycosylation within the linker region for protein stability against proteolytic degradation by the investigation of a large set of mutated CBHI variants (Amore et al. 2017). MD simulations of the interaction of CBHI with crystalline cellulose fibrils further revealed the significance of O-glycosylation for efficient substrate binding (Payne et al. 2013; Amore et al. 2017). Using different expression host as well as $\mathrm{N}$-glycan knockout variants, Kołaczkowski et al. demonstrated that large $\mathrm{N}$-linked glycans do interfere with binding to cellulose. The strongest effect was reported for crystalline cellulose (Avicel) and resulted in a more then twofold increase of the surface loading upon complete N-glycan removal taking into account the density of potential attack sites (Kołaczkowski et al. 2020). On regenerated amorphous cellulose, this effect was much less pronounced which explains the similar substrate affinity we found by SPR measurements using noncrystalline cellulose films.

In our study, the removal of $\mathrm{N}$-linked glycans results in a slightly stronger binding of deglycosylated CBHI to lignin model films from OSL as well as MWL 

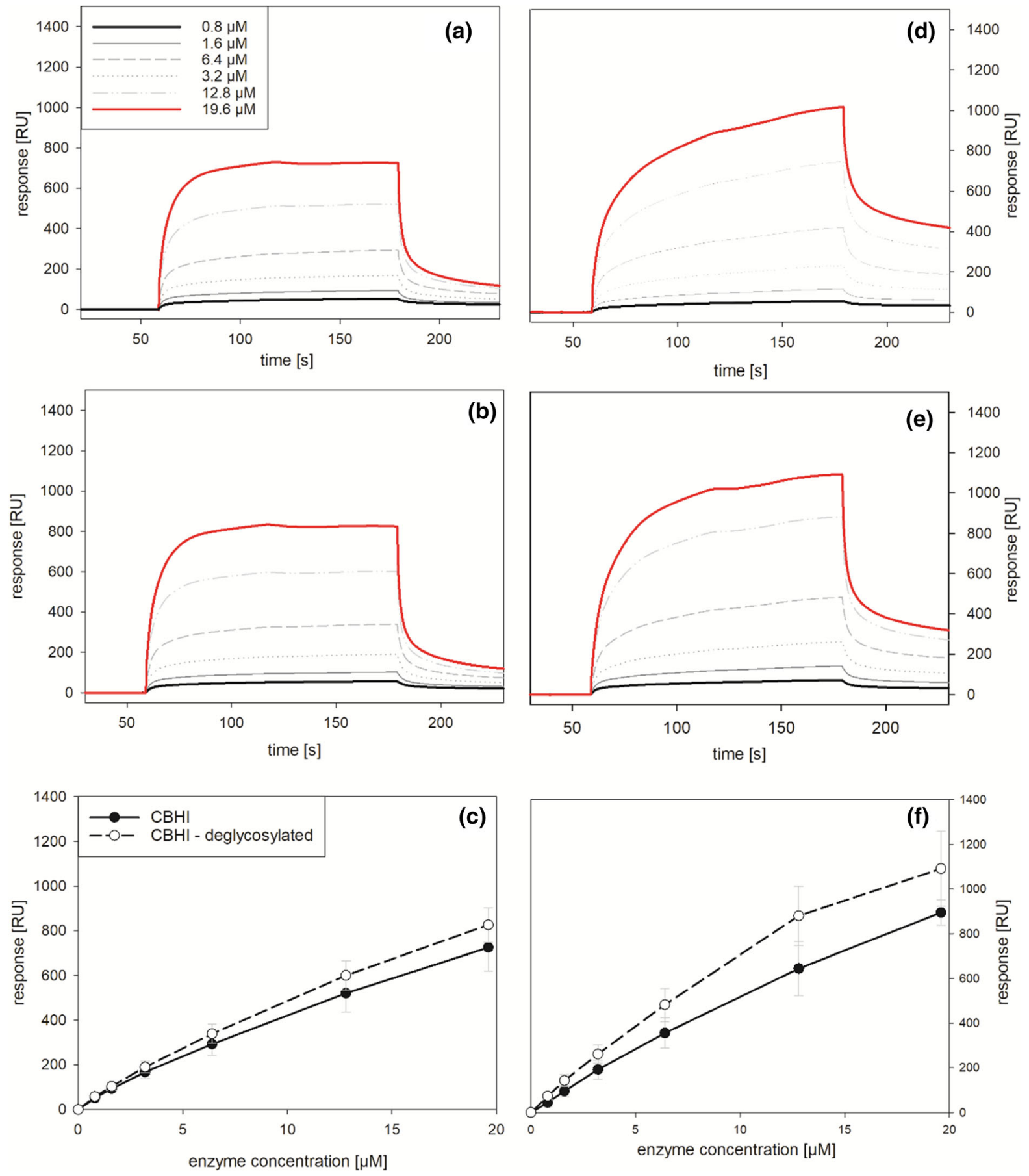

Fig. 6 Binding of CBHI to lignin. Sensograms of multicycle kinetic (MCK) measurements with $\mathrm{CBHI}(\mathbf{a}, \mathbf{d})$ and deglycosylated CBHI $(\mathbf{b}, \mathbf{e})$ were measured with model films prepared from OSL (a, b, c) and MWL $(\mathbf{d}, \mathbf{e}, \mathbf{f})$. The response after $120 \mathrm{~s}$

of contact time vs. enzyme concentration (c, $\mathbf{f})$ is presented as average of four measurements using two independent flow channels

than the untreated enzyme (Fig. 6). The only small difference can be partly explained by the low degree of

glycosylation of CBHI and additionally by the fact that the core GlcNAc unit is not removed by the treatment 
with Endo Hf. Analysis by SDS-PAGE showed a decrease in molecular weight from $60.6 \mathrm{kDa}$ to $59.0 \mathrm{kDa}$ upon deglycosylation with Endo $\mathrm{Hf}$ (Fig. S2).

A slightly higher surface loading could be observed with lignin films prepared from MWL and also the binding was less reversible compared with the films prepared from OSL. MWL is produced by a milder form of extraction procedure yielding a lignin preparation that is more representative for the natural form found in the plant cell wall. Those results demonstrate that the extraction process influences the adsorption properties of lignin. However, the higher adsorption to MWL films could also be explained by the difference between lignin from beech and spruce wood. Previous studies concluded that the S/G ratio influences the adsorption of enzymes and therefore the lower saccharification yield with G-rich lignin showing a higher adsorption capacity (Guo et al. 2014). However, the adsorption capacity and maximal surface loading is also influenced by the surface roughness which was found to be higher for MWL films compared to OSL films. The ratio between reversible and irreversible binding under the conditions used was higher for OSL compared to MWL. At the highest enzyme concentration used in this setup $(19.6 \mu \mathrm{M}$ CBHI) a maximal surface loading of $0.8 \mathrm{mg} \mathrm{m}^{-2}$ on OSL versus $1.2 \mathrm{mg} \mathrm{m}^{-2}$ on MWL films was observed with CBHI.

The same method was applied to study binding of the multienzyme system Celluclast (Fig. 7). The results confirmed the observation made with the isolated CBHI and no significant effect upon removal of N-glycosylation could be identified. This can be explained with the lower number of potential glycosylation sites found in the sequences of the other main components of Celluclast: CBHII and EGs I-V. Therefore, deglycosylation has a higher impact on the isolated CBHI enzyme. Particularly with OSL, different phases in the adsorption process could be observed as a result of the different affinities of the individual enzymes. At the highest concentration used $\left(2 \mathrm{mg} \mathrm{mL}^{-1}\right)$ the maximum surface loading was reached approximately $60 \mathrm{~s}$ after the injection of the enzyme preparations followed by a slow decrease in the signal. Especially with the MWL modified sensor tested with lower enzyme concentrations $\left(0.125-0.25 \mathrm{mg} \mathrm{mL}^{-1}\right)$ a very slow binding to the substrate was found and the equilibrium could not be reached within $120 \mathrm{~s}$ of contact time. This slow adsorption is typical for unspecific binding processes with a low specific affinity. At a $2 \mathrm{mg} \mathrm{mL}^{-1}$ enzyme concentration, the surface loading calculated from the maximal observed response was 2.1 and $1.6 \mathrm{mg} \mathrm{m}^{-2}$ of adsorbed enzyme was determined for OSL and MWL. Using a different buffer system with a higher ionic strength of $50 \mathrm{mM}$, a surface loading of $2.2 \mathrm{mg} \mathrm{m}^{-2}$ on MWL films from spruce using the $\mathrm{CTec} 2$ has been reported which is in good agreement with our findings (Pereira et al. 2017). Particularly with OSL, different phases within the adsorption process could be observed as a result of the different affinities of the individual components of the enzyme mixture. Interestingly, we observed a higher surface loading on OSL compared to MWL using Celluclast. This result indicates that the lignin composition influences the adsorption capacity as well as the fact that different enzymes show different binding tendency for certain types of lignin.

\section{Conclusion}

The characterization of enzyme binding constants by enzyme addition to a substrate dispersion consumes a lot of time and effort. Although films produced from cellulose or lignin are a simplified model for the representation of natural biomass, artificial films are valuable tools to investigate the heterogeneous catalysis of lignocellulolytic enzymes, their binding affinities as well as their tendency for unspecific adsorption to lignin. The model films used in this study were shown to be suitable for the measurement of binding behaviour by SPR. The dissociation constants $\left(K_{\mathrm{D}}\right)$ estimated by SPR of $\sim 1 \mu \mathrm{M}$ for CBHI onto cellulose are in good agreement with the values determined by $\mathrm{UV}-\mathrm{V}$ is spectrometry based measurements and previously reported values. Furthermore, we were able to compare the binding behaviour of Celluclast and isolated CBHI before and after removal of N-glycosylation. Only a minor increase in the binding affinity and surface loading could be detected upon deglycosylation, while the activity and the binding to cellulose was not affected significantly. Based on those results we conclude that the main role of N-linked glycosylation is not prevailingly to prevent non-productive binding to lignin nor is it changing productive binding to cellulosic substrates significantly. Only moderate 

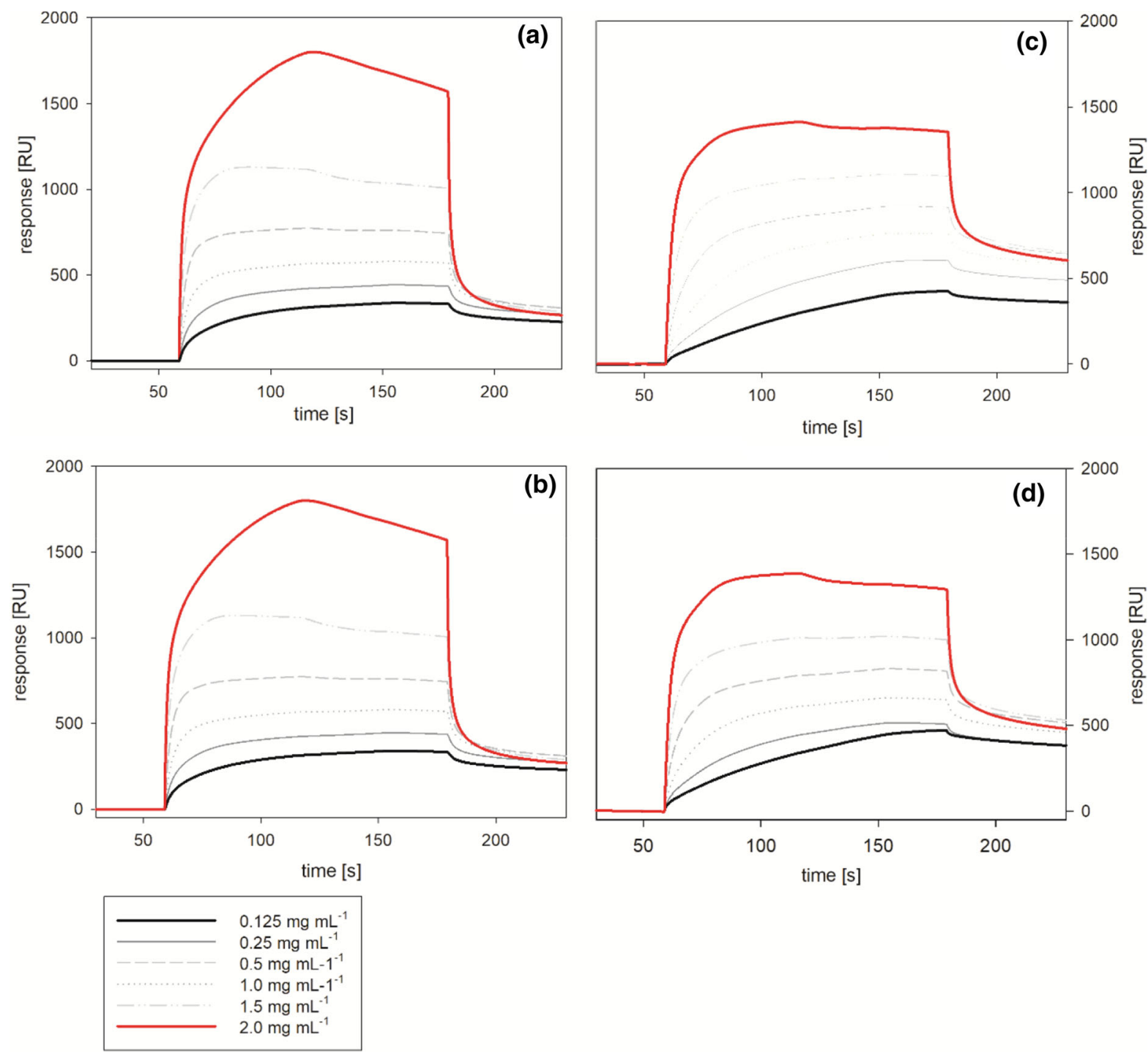

Fig. 7 Binding of Celluclast to lignin. The sensograms of multicycle kinetic (MCK) measurements with Celluclast (a, c) and of deglycosylated Celluclast enzymes (b, d) were measured with model films prepared from OSL (a, b) and MWL (c, d)

differences in non-productive binding to MWL or OSL could be identified which showcases the relevance of this mechanism in the enzymatic processing of native as well as pretreated lignocellulosic feedstocks.

SPR based methods are routinely applied for the high throughput screening of receptor ligands, antibodies and other pharmaceutically relevant compounds. We believe that an SPR method utilizing model films prepared from cellulose, hemicellulose or lignin will reduce analysis time and thereby aid the screening and characterization of enzymes for biopolymer depolymerization.

Acknowledgments We gratefully acknowledge support from the BOKU Core Facility Biomolecular \& Cellular Analysis (BmCA) under the supervision of Dr. Irene Schaffner and Jakob Wallner for SPR analysis. The authors also gratefully thank Gerhard Emsenhuber for technical assistance with contact angle measurements.

Author contributions Conceptualization: FC, RL; Methodology: FC, RL; Formal analysis and investigation: FC, CG, LW; Writing-original draft preparation: FC; Writingreview and editing: FC, CG, LW, GvE, MAK, JK, AP, RL; 
Funding acquisition: RL; Resources: MAK, AP, JK; Supervision: RL.

Funding Open access funding provided by University of Natural Resources and Life Sciences Vienna (BOKU). This project received funding from the European Union's Horizon 2020 research and innovation programme (ERC Consolidator Grant OXIDISE) under grant agreement No 726396. Claudia Gusenbauer gratefully acknowledges support by the Lower Austrian Research and Education Society NFB (Project Number: SC16-004).

\section{Declarations}

Conflict of interest The authors have no conflict of interest to declare that are relevant to the content of this article.

Ethical approval No ethical approval was necessary for this study, which does not involve animal studies or human participants.

Open Access This article is licensed under a Creative Commons Attribution 4.0 International License, which permits use, sharing, adaptation, distribution and reproduction in any medium or format, as long as you give appropriate credit to the original author(s) and the source, provide a link to the Creative Commons licence, and indicate if changes were made. The images or other third party material in this article are included in the article's Creative Commons licence, unless indicated otherwise in a credit line to the material. If material is not included in the article's Creative Commons licence and your intended use is not permitted by statutory regulation or exceeds the permitted use, you will need to obtain permission directly from the copyright holder. To view a copy of this licence, visit http://creativecommons.org/licenses/by/4.0/.

\section{References}

Adney WS, Jeoh T, Beckham GT, Chou YC, Baker JO, Michener W, Brunecky R, Himmel ME (2009) Probing the role of N-linked glycans in the stability and activity of fungal cellobiohydrolases by mutational analysis. Cellulose 16:699-709. https://doi.org/10.1007/s10570-009-9305-1

Alfthan K (1998) Surface plasmon resonance biosensors as a tool in antibody engineering. Biosens Bioelectron 13:653-663. https://doi.org/10.1016/S09565663(98)00020-7

Álvarez C, Reyes-Sosa FM, Díez B (2016) Enzymatic hydrolysis of biomass from wood. Microb Biotechnol 9:149-156. https://doi.org/10.1111/1751-7915.12346

Amore A, Knott BC, Supekar NT, Shajahan A, Azadi P, Zhao P, Wells L, Linger JG, Hobdey SE, Vander Wall TA, Shollenberger T, Yarbrough JM, Tan Z, Crowley MF, Himmel ME, Decker SR, Beckham GT, Taylor LE (2017) Distinct roles of $\mathrm{N}$ - and $\mathrm{O}$-glycans in cellulase activity and stability. Proc Natl Acad Sci USA 114:13667-13672. https://doi. org/10.1073/pnas.1714249114
Aulin C, Ahok S, Josefsson P, Nishino T, Hirose Y, Österberg M, Wågberg L (2009) Nanoscale cellulose films with different crystallinities and mesostructures-Their surface properties and interaction with water. Langmuir 25:7675-7685. https://doi.org/10.1021/la900323n

Berlin A, Gilkes N, Kurabi A, Bura R, Tu M, Kilburn D, Saddler J (2005) Weak lignin-binding enzymes: a novel approach to improve activity of cellulases for hydrolysis of lignocellulosics. Appl Biochem Biotechnol-Part A Enzym Eng Biotechnol 121:163-170. https://doi.org/10.1385/abab: 121:1-3:0163

Berlin A, Balakshin M, Gilkes N, Kadla J, Maximenko V, Kubo S, Saddler J (2006) Inhibition of cellulase, xylanase and $\beta$ glucosidase activities by softwood lignin preparations. J Biotechnol 125:198-209. https://doi.org/10.1016/j. jbiotec.2006.02.021

Björkman A (1954) Isolation of lignin from finely divided wood with neutral solvents. Nature. https://doi.org/10.1038/ $1741057 \mathrm{a} 0$

Borrega M, Päärnilä S, Greca LG, Jääskeläinen AS, Ohra-Aho $\mathrm{T}$, Rojas OJ, Tamminen T (2020) Morphological and wettability properties of thin coating films produced from technical lignins. Langmuir 36:9675-9684. https://doi.org/ 10.1021/acs.langmuir.0c00826

Chandel AK, Garlapati VK, Singh AK, Antunes FAF, da Silva SS (2018) The path forward for lignocellulose biorefineries: bottlenecks, solutions, and perspective on commercialization. Bioresour Technol 264:370-381. https://doi. org/10.1016/j.biortech.2018.06.004

Chen M, Zeng G, Tan Z, Jiang M, Li H, Liu L, Zhu Y, Yu Z, Wei Z, Liu Y, Xie G (2011) Understanding lignin-degrading reactions of ligninolytic enzymes: binding affinity and interactional profile. PLoS ONE 6(9):e25647. https://doi. org/10.1371/journal.pone.0025647

Claeyssens M, Aerts G (1992) Characterisation of cellulolytic activities in commercial Trichoderma reesei preparations: an approach using small, chromogenic substrates. Bioresour Technol 39:143-146. https://doi.org/10.1016/09608524(92)90133-I

Daicho K, Kobayashi K, Fujisawa S, Saito T (2020) Crystallinity-independent yet modification-dependent true density of nanocellulose. Biomacromol 21:939-945. https://doi.org/10.1021/acs.biomac.9b01584

De Bhowmick G, Sarmah AK, Sen R (2018) Lignocellulosic biorefinery as a model for sustainable development of biofuels and value added products. Bioresour Technol 247:1144-1154. https://doi.org/10.1016/j.biortech.2017. 09.163

DiCara DM, Andersen N, Chan R, Ernst JA, Ayalon G, Lazar GA, Agard NJ, Hilderbrand A, Hötzel I (2018) Highthroughput screening of antibody variants for chemical stability: identification of deamidation-resistant mutants. Mabs 10:1073-1083. https://doi.org/10.1080/19420862. 2018.1504726

Ding S-Y, Liu Y-S, Zeng Y, Himmel ME, Baker JO, Bayer EA (2012) How does hemicelluloses removal alter plant cell wall nanoscale architecture and correlate with enzymatic digestibility? Science 338:1055-1060. https://doi.org/10. 1126/science. 1227491

Dos Santos LV, De Barros Grassi MC, Gallardo JCM, Pirolla RAS, Calderón LL, De Carvalho-Netto OV, Parreiras LS, 
Camargo ELO, Drezza AL, Missawa SK, Teixeira GS, Lunardi I, Bressiani J, Pereira GAG (2016) Second-generation ethanol: the need is becoming a reality. Ind Biotechnol 12:40-57. https://doi.org/10.1089/ind.2015. 0017

Eriksson J, Malmsten M, Tiberg F, Callisen TH, Damhus T, Johansen KS (2005a) Enzymatic degradation of model cellulose films. J Colloid Interface Sci 284:99-106. https:// doi.org/10.1016/j.jcis.2004.10.041

Eriksson J, Malmsten M, Tiberg F, Callisen TH, Damhus T, Johansen KS (2005b) Model cellulose films exposed to $\mathrm{H}$. insolens glucoside hydrolase family 45 endo-cellulaseThe effect of the carbohydrate-binding module. J Colloid Interface Sci 285:94-99. https://doi.org/10.1016/j.jcis. 2004.10.042

Eriksson M, Notley SM, Wågberg L (2007) Cellulose thin films: degree of cellulose ordering and its influence on adhesion. Biomacromol 8:912-919. https://doi.org/10.1021/ bm061164w

Guo F, Shi W, Sun W, Li X, Wang F, Zhao J, Qu Y (2014) Differences in the adsorption of enzymes onto lignins from diverse types of lignocellulosic biomass and the underlying mechanism. Biotechnol Biofuels 7:38. https://doi.org/10. 1186/1754-6834-7-38

Hall M, Bansal P, Lee JH, Realff MJ, Bommarius AS (2010) Cellulose crystallinity-A key predictor of the enzymatic hydrolysis rate. FEBS J 277:1571-1582. https://doi.org/10. 1111/j.1742-4658.2010.07585.x

Heinze T (2015) Cellulose: structure and properties. Adv Polym Sci. https://doi.org/10.1007/12_2015_319

Henriksson G, Salumets A, Divne C, Petersson G (1997) Studies of cellulose binding by cellobiose dehydrogenase and a comparison with cellobiohydrolase 1. Biochem J 324:833-838. https://doi.org/10.1042/bj3240833

Himmel ME, Ding SY, Johnson DK, Adney WS, Nimlos MR, Brady JW, Foust TD (2007) Biomass recalcitrance: engineering plants and enzymes for biofuels production. Science 315:804-807. https://doi.org/10.1126/science. 1137016

Horn SJ, Vaaje-kolstad G, Westereng BB, Eijsink VGVGHVG (2012) Novel enzymes for the degradation of cellulose. Biotechnol Biofuels 5:45. https://doi.org/10.1186/17546834-5-45

Hui JPM, Lanthier P, White TC, McHugh SG, Yaguchi M, Roy $R$, Thibault P (2001) Characterization of cellobiohydrolase I (Cel7A) glycoforms from extracts of Trichoderma reesei using capillary isoelectric focusing and electrospray mass spectrometry. J Chromatogr B Biomed Sci Appl 752:349-368. https://doi.org/10.1016/S03784347(00)00373-X

Huntley SK, Ellis D, Gilbert M, Chapple C, Mansfield SD (2003) Significant increases in pulping efficiency in C4HF5H-transformed poplars: improved chemical savings and reduced environmental toxins. J Agric Food Chem 51:6178-6183. https://doi.org/10.1021/jf034320o

Isozaki K, Shimoaka T, Oshiro S, Yamaguchi A, Pincella F, Ueno R, Hasegawa T, Watanabe T, Takaya H, Nakamura M (2018) Robust surface plasmon resonance chips for repetitive and accurate analysis of lignin-peptide interactions. ACS Omega 3:7483-7493. https://doi.org/10.1021/ acsomega.8b01161
Jäger G, Wu Z, Garschhammer K, Engel P, Klement T, Rinaldi R, Spiess AC, Büchs J (2010) Practical screening of purified cellobiohydrolases and endoglucanases with $\alpha$-cellulose and specification of hydrodynamics. Biotechnol Biofuels 3:18. https://doi.org/10.1186/1754-6834-3-18

Jalak J, Väljamäe P (2014) Multi-mode binding of cellobiohydrolase Cel7A from Trichoderma reesei to cellulose. PLoS ONE 9(9):e108181. https://doi.org/10.1371/journal.pone. 0108181

Jeoh T, Ishizawa CI, Davis MF, Himmel ME, Adney WS, Johnson DK (2007) Cellulase digestibility of pretreated biomass is limited by cellulose accessibility. Biotechnol Bioeng 98:112-122. https://doi.org/10.1002/bit

Jeoh T, Michener W, Himmel ME, Decker SR, Adney WS (2008) Implications of cellobiohydrolase glycosylation for use in biomass conversion. Biotechnol Biofuels 1:10. https://doi.org/10.1186/1754-6834-1-10

Josefsson P, Henriksson G, Wågberg L (2008) The physical action of cellulases revealed by a quartz crystal microbalance study using ultrathin cellulose films and pure cellulases. Biomacromol 9:249-254. https://doi.org/10.1021/ bm700980b

Jung LS, Campbell CT, Chinowsky TM, Mar MN, Yee SS (1998) Quantitative interpretation of the response of surface plasmon resonance sensors to adsorbed films. Langmuir 14:5636-5648. https://doi.org/10.1021/la971228b

Kaelble DH (1970) Dispersion-polar surface tension properties of organic solids. J Adhes 2:66-81. https://doi.org/10. 1080/0021846708544582

Kasarova SN, Sultanova NG, Ivanov CD, Nikolov ID (2007) Analysis of the dispersion of optical plastic materials. Opt Mater (amst) 29:1481-1490. https://doi.org/10.1016/j. optmat.2006.07.010

Kittl R, Mueangtoom K, Gonaus C, Khazaneh ST, Sygmund C, Haltrich D, Ludwig R (2012) A chloride tolerant laccase from the plant pathogen ascomycete Botrytis aclada expressed at high levels in Pichia pastoris. J Biotechnol 157:304-314. https://doi.org/10.1016/j.jbiotec.2011.11. 021

Klarskov K, Piens K, Ståhlberg J, Høj PB, Van Beeumen J, Claeyssens M (1997) Cellobiohydrolase I from Trichoderma reesei: Identification of an active-site nucleophile and additional information on sequence including the glycosylation pattern of the core protein. Carbohydr Res 304:143-154. https://doi.org/10.1016/S00086215(97)00215-2

Kołaczkowski BM, Schaller KS, Sørensen TH, Peters GHJ, Jensen K, Krogh KBRM, Westh P (2020) Removal of $\mathrm{N}$-linked glycans in cellobiohydrolase Cel7A from Trichoderma reesei reveals higher activity and binding affinity on crystalline cellulose. Biotechnol Biofuels 13:136. https://doi.org/10.1186/s13068-020-01779-9

Kracher D, Andlar M, Furtmüller PG, Ludwig R (2018) Activesite copper reduction promotes substrate binding of fungal lytic polysaccharide monooxygenase and reduces stability. J Biol Chem 293:1676-1687. https://doi.org/10.1074/jbc. RA117.000109

Laurent CVFP, Sun P, Scheiblbrandner S, Csarman F, Cannazza P, Frommhagen M, van Berkel WJH, Oostenbrink C, Kabel MA, Ludwig R (2019) Influence of lytic polysaccharide monooxygenase active site segments on activity and 
affinity. Int J Mol Sci 20:6219. https://doi.org/10.3390/ ijms20246219

Li Y, Liu X, Lin Z (2012) Recent developments and applications of surface plasmon resonance biosensors for the detection of mycotoxins in foodstuffs. Food Chem 132:1549-1554. https://doi.org/10.1016/j.foodchem.2011.10.109

Lourenço A, Pereira H (2018) Compositional variability of lignin in biomass. In: Poletto M (ed): Lignin-Trends and Applications. InTech. https://doi.org/10.5772/intechopen. 71208

Mariani S, Minunni M (2014) Surface plasmon resonance applications in clinical analysis. Anal Bioanal Chem 406:2303-2323. https://doi.org/10.1007/s00216-0147647-5

Merino ST, Cherry J (2007) Progress and challenges in enzyme development for biomass utilization. Adv Biochem Eng Biotechnol 108:95-120. https://doi.org/10.1007/10_2007_ 066

Mohan T, Kargl R, Doliška A, Vesel A, Köstler S, Ribitsch V, Stana-Kleinschek K (2011) Wettability and surface composition of partly and fully regenerated cellulose thin films from trimethylsilyl cellulose. J Colloid Interface Sci 358:604-610. https://doi.org/10.1016/j.jcis.2011.03.022

Nakagame S, Chandra RP, Kadla JF, Saddler JN (2011) The isolation, characterization and effect of lignin isolated from steam pretreated Douglas-fir on the enzymatic hydrolysis of cellulose. Bioresour Technol 102:4507-4517. https:// doi.org/10.1016/j.biortech.2010.12.082

Nečas D, Klapetek P (2012) Gwyddion: an open-source software for SPM data analysis. Cent Eur J Phys 10:181-188. https://doi.org/10.2478/s11534-011-0096-2

Nelson N (1944) A photometric adaption of the Somogyi method for the determination of glucose. J Biol Chem 153:375-380

Norgren M, Notley SM, Majtnerova A, Gellerstedt G (2006) Smooth model surfaces from lignin derivatives. I Prep Charact Langmuir 22:1209-1214. https://doi.org/10.1021/ la052284c

Notley SM, Norgren M (2010) Surface energy and wettability of spin-coated thin films of lignin isolated from wood. Langmuir 26:5484-5490. https://doi.org/10.1021/ la1003337

Olaru A, Bala C, Jaffrezic-Renault N, Aboul-Enein HY (2015) Surface plasmon resonance (SPR) biosensors in pharmaceutical analysis. Crit Rev Anal Chem 45:97-105. https:// doi.org/10.1080/10408347.2014.881250

Owens DK, Wendt RC (1969) Estimation of the surface free energy of polymers. J Appl Polym Sci 13:1741-1747

Palonen H, Tjerneld F, Zacchi G, Tenkanen M (2004) Adsorption of Trichoderma reesei CBH I and EG II and their catalytic domains on steam pretreated softwood and isolated lignin. J Biotechnol. https://doi.org/10.1016/j.jbiotec. 2003.09.011

Pan X (2008) Role of functional groups in lignin inhibition of enzymatic hydrolysis of cellulose to glucose. J Biobased Mater Bioenergy 2:25-32. https://doi.org/10.1166/jbmb. 2008.005

Pareek N, Gillgren T, Jönsson LJ (2013) Adsorption of proteins involved in hydrolysis of lignocellulose on lignins and hemicelluloses. Bioresour Technol 148:70-77. https://doi. org/10.1016/j.biortech.2013.08.121
Patching SG (2014) Surface plasmon resonance spectroscopy for characterisation of membrane protein-ligand interactions and its potential for drug discovery. Biochim Biophys Acta-Biomembr 1838:43-55. https://doi.org/10.1016/j. bbamem.2013.04.028

Payne CM, Resch MG, Chen L, Crowley MF, Himmel ME, Taylor LE, Sandgren M, Stahlberg J, Stals I, Tan Z, Beckham GT (2013) Glycosylated linkers in multimodular lignocellulose-degrading enzymes dynamically bind to cellulose. Proc Natl Acad Sci USA 110:14646-14651. https://doi.org/10.1073/pnas.1309106110

Percival Zhang YH, Himmel ME, Mielenz JR (2006) Outlook for cellulase improvement: screening and selection strategies. Biotechnol Adv 24:452-481. https://doi.org/10.1016/ j.biotechadv.2006.03.003

Pereira A, Hoeger IC, Ferrer A, Rencoret J, Del Rio JC, Kruus K, Rahikainen J, Kellock M, Gutiérrez A, Rojas OJ, Rio JC, Kruus K, Rahikainen J, Kellock M, Gutie A, Rojas OJ, Del Rio JC, Kruus K, Rahikainen J, Kellock M, Gutiérrez A, Rojas OJ (2017) Lignin films from spruce, eucalyptus, and wheat straw studied with electroacoustic and optical sensors: effect of composition and electrostatic screening on enzyme binding. Biomacromol 18:1322-1332. https:// doi.org/10.1021/acs.biomac.7b00071

Piliarik M, Párová L, Homola J (2009) High-throughput SPR sensor for food safety. Biosens Bioelectron 24:1399-1404. https://doi.org/10.1016/j.bios.2008.08.012

Pu Y, Zhang D, Singh PM, Ragauskas AJ (2008) The new forestry biofuels sector. Biofuels, Bioprod Biorefining 2:58-73. https://doi.org/10.1002/bbb.48

Qi F, Zhang W, Zhang F, Chen G, Liu W (2014) Deciphering the effect of the different $\mathrm{N}$-glycosylation sites on the secretion, activity, and stability of cellobiohydrolase i from Trichoderma reesei. Appl Environ Microbiol 80:3962-3971. https://doi.org/10.1128/AEM.00261-14

Quillin ML, Matthews BW (2000) Accurate calculation of the density of proteins. Acta Crystallogr Sect D Biol Crystallogr 56:791-794. https://doi.org/10.1107/ S090744490000679X

Ragauskas AJ, Williams CK, Davison BH, Britovsek G, Cairney J, Eckert CA, Frederick WJ, Hallett JP, Leak DJ, Liotta CL, Mielenz JR, Murphy R, Templer R, Tschaplinski T (2006) The path forward for biofuels and biomaterials. Science 311:484-489. https://doi.org/10.1126/science.1114736

Ragauskas AJ, Beckham GT, Biddy MJ, Chandra R, Chen F, Davis MF, Davison BH, Dixon RA, Gilna P, Keller M, Langan P, Naskar AK, Saddler JN, Tschaplinski TJ, Tuskan GA, Wyman CE (2014) Lignin valorization: improving lignin processing in the biorefinery. Science 344:1246843-1246843. https://doi.org/10.1126/science. 1246843

Rahikainen JL, Martin-Sampedro R, Heikkinen H, Rovio S, Marjamaa K, Tamminen T, Rojas OJ, Kruus K (2013) Inhibitory effect of lignin during cellulose bioconversion: the effect of lignin chemistry on non-productive enzyme adsorption. Bioresour Technol 133:270-278. https://doi. org/10.1016/j.biortech.2013.01.075

Raj G, Balnois E, Baley C, Grohens Y (2012) CHAPTER 9. Probing Interfacial Interactions in Natural Fibre Reinforced Biocomposites Using Colloidal Force Microscopy. In: John MJ, Sabu T (eds) Natural Polymers. Volume 1: 
Composites. The Royal Society of Chemistry: Cambridge, UK, pp 183-203

Rinaldi R, Jastrzebski R, Clough MT, Ralph J, Kennema M, Bruijnincx PCA, Weckhuysen BM (2016) Paving the way for lignin valorisation: recent advances in bioengineering, biorefining and catalysis. Angew Chemie - Int Ed 55:8164-8215. https://doi.org/10.1002/anie.201510351

Rosgaard L, Pedersen S, Langston J, Akerhielm D, Cherry JR, Meyer AS (2007) Evaluation of minimal Trichoderma reesei cellulase mixtures on differently pretreated barley straw substrates. Biotechnol Prog 23:1270-1276. https:// doi.org/10.1021/bp070329p

Salas C, Rojas OJ, Lucia LA, Hubbe MA, Genzer J (2013) On the surface interactions of proteins with lignin. ACS Appl Mater Interfaces 5:199-206. https://doi.org/10.1021/ am3024788

Sammond DW, Yarbrough JM, Mansfield E, Bomble YJ, Hobdey SE, Decker SR, Taylor LE, Resch MG, Bozell JJ, Himmel ME, Vinzant TB, Crowley MF (2014) Predicting enzyme adsorption to lignin films by calculating enzyme surface hydrophobicity. J Biol Chem 289:20960-20969. https://doi.org/10.1074/jbc.M114.573642

Schutyser W, Renders T, Van Den Bosch S, Koelewijn SF, Beckham GT, Sels BF (2018) Chemicals from lignin: an interplay of lignocellulose fractionation, depolymerisation, and upgrading. Chem Soc Rev 47:852-908. https://doi.org/ $10.1039 / \mathrm{c} 7 \mathrm{cs} 00566 \mathrm{k}$

Sczech R, Riegler H (2006) Molecularly smooth cellulose surfaces for adhesion studies. J Colloid Interface Sci 301:376-385. https://doi.org/10.1016/j.jcis.2006.05.021

Sipponen MH, Rahikainen J, Leskinen T, Pihlajaniemi V, Mattinen M-L, Lange H, Crestini C, Österberg M (2017) Structural changes of lignin in biorefinery pretreatments and consequences to enzyme-lignin interactions. Nord Pulp Pap Res J 32:550-571. https://doi.org/10.3183/npprj2017-32-04-p550-571

Siqueira G, Arantes V, Saddler JN, Ferraz A, Milagres AMF (2017) Limitation of cellulose accessibility and unproductive binding of cellulases by pretreated sugarcane bagasse lignin. Biotechnol Biofuels 10:176. https://doi.org/ 10.1186/s13068-017-0860-7

Situ C, Mooney MH, Elliott CT, Buijs J (2010) Advances in surface plasmon resonance biosensor technology towards high-throughput, food-safety analysis. TrAC-Trends Anal Chem 29:1305-1315. https://doi.org/10.1016/j.trac. 2010.09.003

Somogyi M (1952) Notes on sugar determination. J Biol Chem 195:19-23

Stals I, Sandra K, Geysens S, Contreras R, Van Beeumen J, Claeyssens M (2004) Factors influencing glycosylation of Trichoderma reesei cellulases. I: postsecretorial changes of the O- and N-glycosylation pattern of Ce17A. Glycobiology 14:713-724. https://doi.org/10.1093/glycob/cwh080

Suchy M, Linder MB, Tammelin T, Campbell JM, Vuorinen T, Kontturi E (2011) Quantitative assessment of the enzymatic degradation of amorphous cellulose by using a quartz crystal microbalance with dissipation monitoring. Langmuir 27:8819-8828. https://doi.org/10.1021/la2014418

Teleman A (2009) Chapter 5. Hemicelluloses and pectins. In: Ek M, Gellerstedt G, Henriksson G (eds) Wood chemistry and wood biotechnology, DeGryter, vol 1, pp 102-120. https:// doi.org/10.1515/9783110213409.101

Tokunaga Y, Nagata T, Kondo K, Katahira M, Watanabe T (2020) NMR elucidation of nonproductive binding sites of lignin models with carbohydrate-binding module of cellobiohydrolase I. Biotechnol Biofuels 13:164. https://doi. org/10.1186/s13068-020-01805-w

Triwulandari E, Ghozali M, Sondari D, Septiyanti M, Sampora Y, Meliana Y, Fahmiati S, Restu WK, Haryono A (2019) Effect of lignin on mechanical, biodegradability, morphology, and thermal properties of polypropylene/polylactic acid/lignin biocomposite. Plast Rubber Compos 48:82-92. https://doi.org/10.1080/14658011.2018. 1562746

Vaaje-Kolstad G, Westereng B, Horn SJ, Liu Z, Zhai H, Sørlie M, Eijsink VGGH (2010) An oxidative enzyme boosting the enzymatic conversion of recalcitrant polysaccharides. Science 219:219-223. https://doi.org/10.1126/science. 1192231

Van Erven G, De Visser R, De Waard P, Van Berkel WJH, Kabel MA (2019) Uniformly ${ }^{13} \mathrm{C}$ labeled lignin internal standards for quantitative pyrolysis-GC-MS analysis of grass and wood. ACS Sustain Chem Eng 7:20070-20076. https://doi.org/10.1021/acssuschemeng.9b05926

Vörös J (2004) The density and refractive index of adsorbing protein layers. Biophys J 87:553-561. https://doi.org/10. 1529/biophysj.103.030072

Weißl M, Niegelhell K, Reishofer D, Zankel A, Innerlohinger J, Spirk S (2018) Homogeneous cellulose thin films by regeneration of cellulose xanthate: properties and characterization. Cellulose 25:711-721. https://doi.org/10.1007/ s10570-017-1576-3

Willard L, Ranjan A, Zhang H, Monzavi H, Boyko RF, Sykes BD, Wishart DS (2003) VADAR: a web server for quantitative evaluation of protein structure quality. Nucleic Acids Res 31:3316-3319. https://doi.org/10.1093/nar/ gkg565

Wohlschlager L, Csarman F, Chang H, Fitz E, Seiboth B, Ludwig R (2021a) Heterologous expression of Phanerochaete chrysosporium cellobiose dehydrogenase in Trichoderma reesei. Res Sq. https://doi.org/10.1186/s12934020-01492-0

Wohlschlager L, Csarman F, Zrili M, Seiboth B, Ludwig R, Zrilić M, Seiboth B, Ludwig R (2021b) Comparative characterization of glyoxal oxidase from Phanerochaete chrysosporium expressed at high levels in Pichia pastoris and Trichoderma reesei. Enzyme Microb Technol. https:// doi.org/10.1016/j.enzmictec.2021.109748

Wood TM (1988) Preparation of crystalline, amorphous, and dyed cellulase substrates. Methods Enzymol 160:19-25. https://doi.org/10.1016/0076-6879(88)60103-0

Yamaguchi A, Isozaki K, Nakamura M, Takaya H, Watanabe T (2016) Discovery of 12-mer peptides that bind to wood lignin. Sci Rep 6:21833. https://doi.org/10.1038/srep21833

Yoo CG, Dumitrache A, Muchero W, Natzke J, Akinosho H, Li M, Sykes RW, Brown SD, Davison B, Tuskan GA, Pu Y, Ragauskas AJ (2018) Significance of lignin S/G ratio in biomass recalcitrance of Populus trichocarpa variants for bioethanol production. ACS Sustain Chem Eng 6:2162-2168. https://doi.org/10.1021/acssuschemeng. $7 \mathrm{~b} 03586$ 
Zinovyev G, Sulaeva I, Podzimek S, Rössner D, Kilpeläinen I, Sumerskii I, Rosenau T, Potthast A (2018) Getting closer to absolute molar masses of technical lignins. Chemsuschem 11:3259-3268. https://doi.org/10.1002/cssc.201801177

Zoghlami A, Paës G (2019) Lignocellulosic biomass: understanding recalcitrance and predicting hydrolysis. Front Chem 7:874. https://doi.org/10.3389/fchem.2019.00874
Publisher's Note Springer Nature remains neutral with regard to jurisdictional claims in published maps and institutional affiliations. 